\title{
Comparing the Efficiency of Italian Public and Private Universities (2007-2011): An Empirical Analysis
}

\author{
Tommaso Agasisti ${ }^{1}$ • Luisa Ricca ${ }^{2}$
}

Received: 28 December 2014 / Accepted: 17 July 2015 / Published online: 4 August 2015

(C) Società Italiana degli Economisti (Italian Economic Association) 2015

\begin{abstract}
The aim of this study is to analyse the technical efficiency of Italian public and private universities. We therefore conduct a Data Envelopment Analysis on Italian universities in the years 2007-2011, using a novel integrated dataset from the Statistical Office of the Ministry of Education and from the National Agency for Evaluation. The inputs of the model are the total number of students and faculty staff, while the outputs are the total number of graduates and the revenues from scientific research. The results show differences related to the type of universities (private universities are relatively more efficient than public ones) and geographical area (Northern universities are relatively more efficient than those of the Centre and South). The Malmquist index, used for a comparison of different years, shows that the overall efficiency of Italian universities has increased in the period examined, particularly thanks to pure efficiency.
\end{abstract}

Keywords Efficiency $\cdot$ Higher education $\cdot$ Private universities $\cdot$ Malmquist index

JEL Classification $\quad \mathrm{I} 21 \cdot \mathrm{I} 23 \cdot \mathrm{C} 14$

\section{Introduction and Research Objectives}

Recent years have been characterized by a continuous decreasing of public funding for public and welfare services. In the higher education (HE) sector, institutions have to prove higher education to a growing population without a simultaneous increasing in government funding. The greater autonomy given to Italian universities in the last

\footnotetext{
$\bowtie$ Tommaso Agasisti tommaso.agasisti@polimi.it

1 Politecnico di Milano School of Management, Milan, Italy

2 IULM University, Milan, Italy
} 
years has also led to more competition in order to increase their efficiency "producing" a greater amount of teaching (more students) and a better quality of research.

Public financial funding for Italian public universities have decreased by approximately $15 \%$ from 2009 to 2013 (author's estimation on Ministry of Education data); ${ }^{1}$ the same data for private universities shows that funds have decreased by $22 \%$ in the same years, in addition to the fact that there are now more beneficiaries. ${ }^{2}$

It is also interesting to reflect on the relevance of the Italian private institutions. They receive a small amount of funds, but it is recognized the role that they play in the national system: private universities, such as public ones, respond to the needs and interests of the society and the business world, producing and transferring knowledge through research and teaching. It can therefore be concluded that the state should also fund private universities as a "reward" for the production to which they contribute (education) and that has a positive effect on the country.

In a context like this, it becomes increasingly important, also for public policies, to analyse the efficiency of universities, in order to understand how productive they are. The efficiency analysis can be used as an indirect evaluation of the utilization of funding, in spite it derives from public sources (such as in the case of public universities) or private sources (in the case of private universities).

The aim of this research is to analyse the technical efficiency of the Italian public and private universities over 5 years (2007-2011), in order to investigate whether there is an efficiency differential between public and private system, and if this efficiency is decreased or increased over the years. While many recent studies deal with the efficiency of Italian universities (see, for instance, a review in Agasisti and Lezzi 2013), this paper is innovative in that is the first that explicitly compares the relative efficiency of public and private institutions.

The efficiency analysis has been conducted through Data Envelopment Analysis (DEA), a nonparametric approach that does not require any prior assumption on the functional form of the relationship between inputs and outputs and on the distribution of the efficiency scores. While there is no agreement about the exact functioning of the universities' production processes, the existing literature suggests the use of nonparametric techniques for estimating their efficiency (see the discussion in Worthington 2001; Johnes 2004), as these methods allows not formulating specific hypotheses about the economic behaviour (i.e. do not impose assumptions about their cost-minimization attitude). The present study, also, uses a statistically-robust version of DEA (following Simar and Wilson 2000) that is less subject to some traditional weaknesses of DEA due to its deterministic nature.

Anticipating our results, we can say that we have found differences related to the type of universities (private universities seem to be relatively more efficient than public ones) and geographical area (Northern universities seem relatively more efficient than those of the centre and the South). The analysis of Malmquist index has also showed that the overall efficiency of Italian universities has increased over the period examined.

\footnotetext{
1 Although it should be noted that until the year 2009 the funding for state universities have seen a continuous growth.

2 In addition to the 14 private universities member of CRUI (the Conference of Italian University Rectors), others 5 have been added to beneficiaries of public funds, including 2 telematic universities.
} 
The remainder of the paper is organized as follows: in Sect. 2 a brief analysis of the Italian context is shown, while in Sect. 3 we present a literature review. Section 4 illustrates and explains the reasons for the methodology adopted and presents the data used. Section 5 illustrates the main results, while Sect. 6 concludes.

\section{Background: The Private University System in Italy}

In the last half century, the private sector of higher education has grown very rapidly (Levy 2012). This has also taken place in the European context, in spite of the traditional public role attributed to higher education.

The separation between the public and the private sector is not always clearly defined and it is often possible to find a precise definition only looking at the national legislations: the distinction between the two systems is therefore purely legal. Within the same sector, private institutions can then be for-profit or not, although the latter option appears the most common.

There are two aspects that can distinguish the private sector from the public:

- financial contribution, which clearly must derive mostly from private sources, while the public sector is mainly financed through government funds;

- a stronger autonomy, which allows private universities to decide forms of governance or to have more freedom, particularly in relation to decisions on financial policy.

To better know the private higher education system, it can be interesting have a look at some data. Using data from EUROSTAT it is possible to compare enrolment rates of public and private institutions in several states. As can be seen in Fig. 1, private institutions generally attract fewer students than public ones, representing a $10.6 \%$ at European level, ${ }^{3}$ about $28 \%$ in United States and $80 \%$ in Japan. Among European countries there is a high variability, with peaks of $67 \%$ in Cyprus and $31 \%$ in Poland and Romania.

The great difference in enrolment rates between European and non-European countries can derive from the typical European idea of university as a public good that should be funded by the state. This is not surprising considering that Europe is the birthplace of the so-called "continental model" of higher education provision (Clark 1983), which sees the state at the centre of the higher education system, governing the funding and defining rules and practices. Higher education is considered a public good, and for this reason there is a strong opposition to the privatization of public universities and to public funding of private institutions.

The variation in enrolment rates in private institutions in the decade 2001-2011 shows that the states in which the variation is negative are very few and in the majority of countries the enrolment rate at private institutions have increased over the period, reflecting the growing importance assumed by this system. The variation is even more important for countries of Central and Eastern Europe, but also for Africa and much of Latin America. It is easy to assume that where the ageing of population is higher and

\footnotetext{
3 These percentages are calculated considering only private institutions independent from the state; private institutions dependent from the state receive more than half of their funds from the state itself.
} 


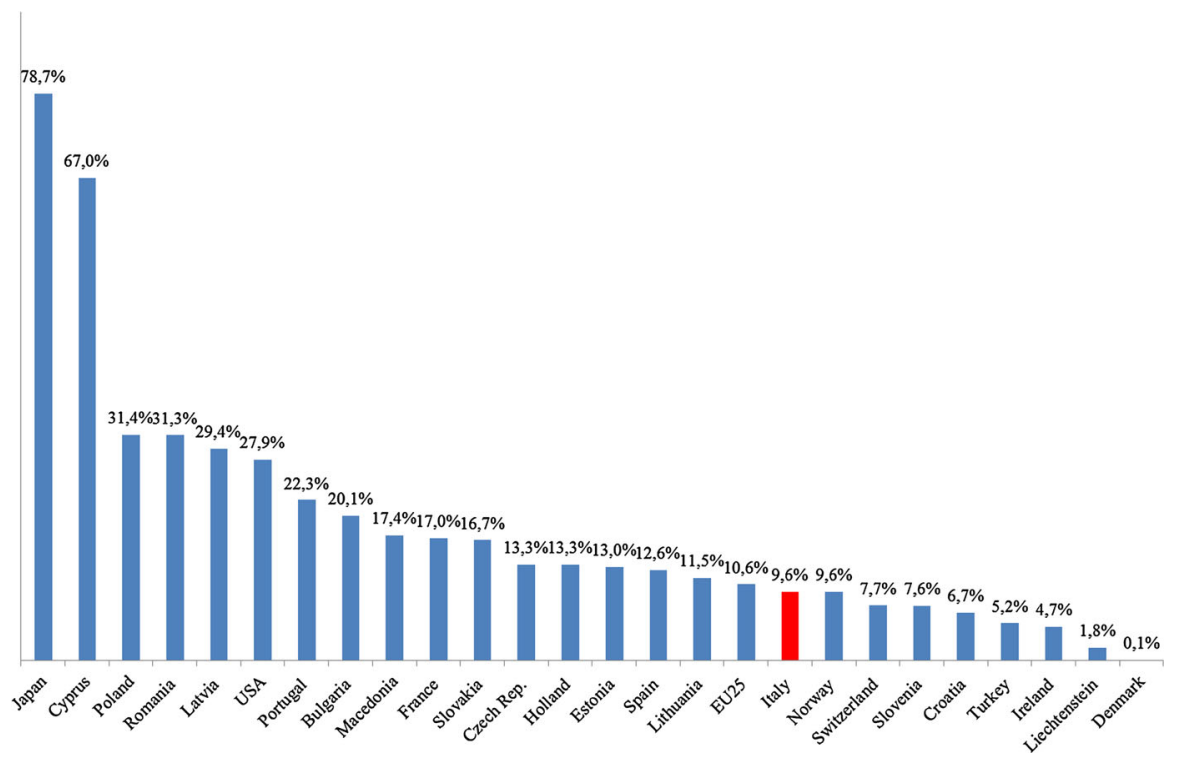

Fig. 1 Enrolment rate to "private institution independent from the state". Source Author's elaboration from EUROSTAT 2011 (Eurostat defines private universities according to the type of governance of the institution and for this reason, given the strong autonomy of the English system here it is reported as $100 \%$ private but dependent from the state)

the school-age population is declining, the competition among universities to attract students is expected to grow. In these countries, only the best institutions considered innovative and with quality, will be able to compete successfully, whether they are public or private.

The Italian setting is characterized by some particular specificity. The first Italian universities (universitates studiorum) where founded in the Middle Ages in cities like Bologna. They born as places to defend rights and privileges of students and scholars, but they soon became places for cultural debate, study and research, open to scholars of any nationality. Other universitates studiorum were founded by popes, emperors and kings, such as the Università degli studi di Napoli Federico II, which was founded in 1224 by Frederick II of Swabia and King of Naples. Over the centuries, universities were gradually transformed into public institutions under the control of the government; this fact has led to the highly centralized nature of the Italian university system until the 80 's. The Italian HE system has been reformed in recent years to join the Bologna Process. It currently consists of 96 institutions:

- 67 public universities (including 8 special schools);

- 18 private universities legally recognized;

- 11 telematics private universities legally recognized.

An important characteristic is the "legal value" of the degree, which means that graduates are considered at the same level of knowledge and competence regardless of the university in which they studied. Therefore any kind of differentiation between the institutions exists: all universities are formally (i.e. legally) equal. 
The possibility for private to operate in the higher education system is defined in the Constitution itself, which in the article 33 states that "Private have the right to found schools and institutions without any additional cost for the state". Private universities can then be promoted by private parties, and can be of the following different types:

- university strongly linked to the territory in which they born;

- universities inspired by religious principles;

- universities that meet specific need of a part of the civil society and productive sectors and born to create specific job profiles.

The universities' autonomy is assured both for public and private institutions, but all of them must comply with certain rules and requirements, in particular with regard to the structure of the curricula. In order to ensure a uniform level of knowledge (needed for the legal validity of the degree) subjects' areas to be taught are balanced directly by the Ministry of Education. Universities must also comply with various ministerial constraints for the composition of the teaching staff, the teacher/student ratio and the minimum number of professors to have for single programs.

At the ministerial level, the distinctions between public and private universities are few, the most important is the type and amount of funding and the way of allocation.

Private universities offer a wide range of disciplines, although they are mainly concentrated on social and political areas.

According to the Ministry of Education's Statistical Office in the academic year 2012/2013 students enrolled in private universities (excluding the telematics) were $5.7 \%$ of the total and students enrolled at the 1 st year were $6.5 \%$ of the total.

The current Italian model of public funding for higher education, in force since 2003, is based on three pillars:

- the ordinary financing fund for universities (FFO);

- the fund for university buildings and scientific equipment;

- the fund for the university system's development.

The FFO is the annual contribution that public universities receive from the government. It represents the bulk of revenues for public universities, and it is today made up of a base (proportional to the historical allocation for each university) and a part established in relation to incentives. The allocation is therefore based on a formula-based mechanism, where a part is however fixed. It should be noted that the part paid on the basis of competition is small compared to the part distributed for historical allocations, albeit growing. ${ }^{4}$ In 2010, the contribution received from fees of the students in public universities amounted to $8.5 \%$ of the total revenues.

With regard to private universities, according to the Law 243 of 1991, "the State may give contributions, within the limits established by this Law, to private universities and higher education institutions that have been legally authorized to give degree with legal validity". This contribution covers a minority share of the total budget of private

4 In 2010 the $80 \%$ of FFO has been erogated on historical base and only a $10.2 \%$ has been erogated by competitive funding (Turri 2011). In 2014, $18 \%$ of FFO is assigned following the premium formula. 


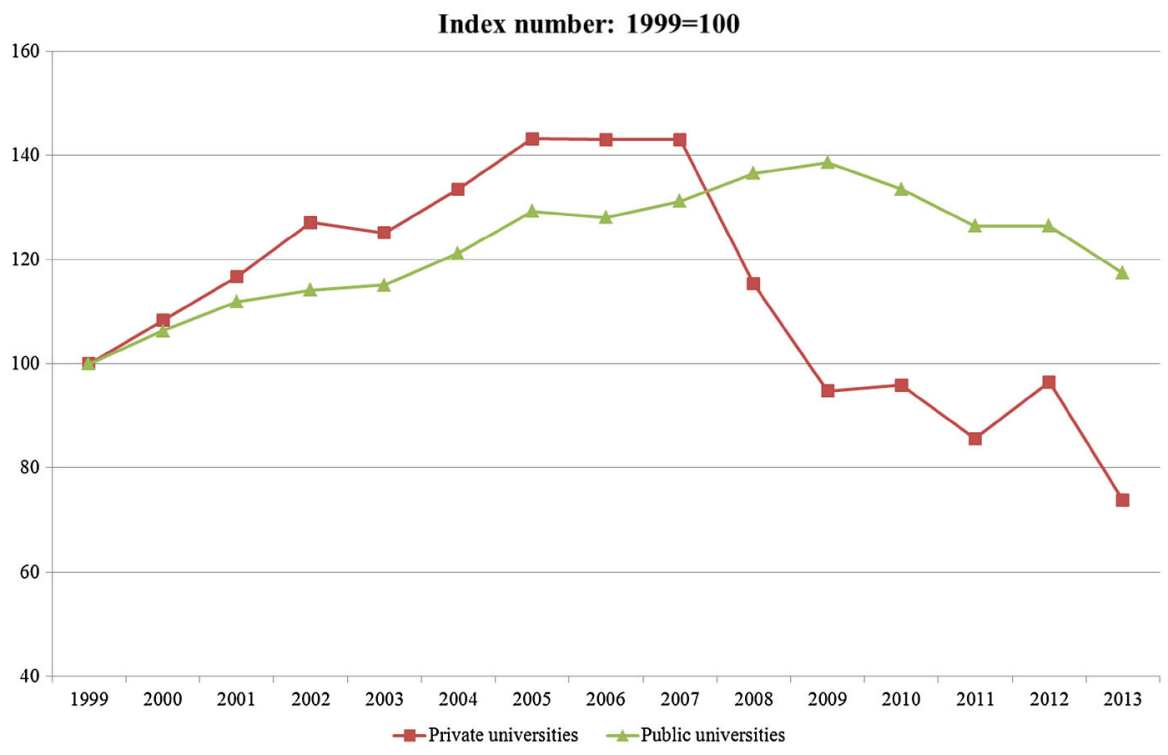

Fig. 2 Public funding to Italian universities, years 1999-2013

universities, which are mostly self-financed through student fees. In 2010 revenues from student fees corresponded to the $35.7 \%$ of total revenues. ${ }^{5}$ The amount of the contribution for private institutions (that is a separated fund from FFO) is the result of a part proportional to the historical transfer, a part as a balance for the shortfall of university fees due to the increase (if any) of total grants for students comparing to those granted in the academic year 2000/2001 and a part established on the basis of competition. ${ }^{6}$ To this contribution it can be added a "una tantum" amount for specific purposes.

The total funds for private universities have dropped sharply in recent years, ${ }^{7}$ more than the one for public universities. Moreover, the dynamic of public funds reveals that in recent years the policies realised by various governments, despite the different political orientations, have been quite similar-i.e. reducing the total amount of public sources devoted to private HEIs, and this is an additional force that potentially stimulated their efficiency. Politically, in Italy has always been easier to cut (public) educational spending for private institutions than public ones; when attempts about the latter have been made, they were adverse by strong protests by politicians, institutions and unions (Fig. 2).

\footnotetext{
5 If we exclude universities "linked to the territory" that are largely funded by the Provinces (Aosta and Bolzano), the value is even higher and equal to $40 \%$.

6 In 2010 the $80 \%$ of FFO has been erogated on historical base, a $11.2 \%$ as balance for shortfall of fees and a $8.8 \%$ has been erogated by competitive funding (Turri 2011).

7 It must also be noted that in recent years have had access to such funding also some telematics universities: the portion of the contribution, already resized, is now divided among a larger number of universities.
} 


\section{Literature Review About the Efficiency of Italian Universities}

Measuring universities' efficiency has become one of the central themes in the studies related to higher education since the early 1990s. In those years researchers began to consider improvement in efficiency of the institutions as a way to cope with the new challenges that the system had to face (Johnes 1993). It is possible to conduct efficiency analysis using various techniques; the first studies were implemented using the linear regression model (OLS) in order to investigate the changes in output in presence of a reduction of the input (Johnes and Taylor 1990).

Universities are institutions that use a multitude of inputs in their "production process" to produce at least two outputs (graduates and research). For this reason the analysis of universities' performance have abandoned the use of the linear regression in favor of the adoption of most suitable methods such as the analysis of the stochastic frontier (SFA) and Data Envelopment Analysis (DEA) (Johnes 2006a).

In this section, we review some previous contributions that focused on the efficiency of Italian universities. Some early studies have investigated the efficiency of single institutions, looking at the differences between the departments of a university (Pesenti and Ukovich 1999; Rizzi 1999), while most recent ones have analyzed the efficiency of the university system as a whole (Agasisti and Dal Bianco 2006; Monaco 2012; Bergantino et al. 2012; Agasisti and Lezzi 2013) or comparing different countries (Agasisti and Johnes 2009; Agasisti and Pérez-Esparrels 2010; Agasisti and Pohl 2012).

Agasisti and Johnes (2009), in their comparison of the technical efficiency of Italian and English universities, have demonstrated that universities in UK are more efficient, even if the Italian institutions show an improvement in efficiency over the years. Agasisti and Pérez-Esparrels (2010) have carried out a similar analysis comparing Italian and Spanish universities, showing that both countries have a good level of efficiency, with Italian institutions more efficient than Spanish ones. The comparison between Germany and Italy by Agasisti and Pohl (2012) shows more efficiency among German universities, but with a more rapid improvement for Italian universities. In both countries, it is also noted a geographical differentiation: North-South in Italy, East-West in Germany.

Regarding the studies on the Italian system, Agasisti and Dal Bianco (2006) analysed the efficiency of 58 Italian public universities, highlighting the existence of a small set of universities that can be considered as "best-practice", mainly located in Northern Italy. The analysis also showed how efficiency analysis could be of support to the formulation of policy to reward universities in base of their performance.

Monaco (2012), analyzing data for the academic year 2009/2010, shows that private universities have higher efficiency values than public ones. Differences in efficiency can be also seen in relation to geographical location: the universities in the North are more efficient than those in the South.

Bergantino et al. (2012) conducted an analysis to investigate the role of competition in determining incentives to improve efficiency, showing that when universities operate in a more competitive environment they are also inducted to improve their efficiency. 
Agasisti and Lezzi (2013), implementing the DEA model on a dataset of 55 Italian public universities, showed a better performance of Northern universities, and demonstrated that the reforms due to the Bologna Process have led to a change in the efficiency frontier. The authors have finally found a strong positive association between efficiency and the revenues from student fees.

To this day, there are two main gaps in this literature, because there is not any study that analyses the differences between public and private higher education sector in Italy considering several years. These are the reasons that make this study innovative: (i) it takes into account at the same time public and private institutions; and (ii) it analyses the intertemporal evolution of the efficiency in a 5-year period.

As the primary intention of this research has been to fill the gap and obtain a comparison between public and private Italian universities, we decided to sacrifice completeness of data, implementing a simplified model of the productive process. Prior studies have often concentrated only on public universities, because not all the data used (especially when conducting a comparison between countries) were publicly available also for private institutions. The simplification of the production model has instead allowed us to analyse at the same time both types of universities.

\section{Methodology and Data}

There are three different types of efficiency (Johnes 2004): technical efficiency, allocative efficiency and economic efficiency.

The present analysis is focused on the analysis of technical efficiency, because we do not have information about the differential process of inputs, and also because they are not very homogeneous across the various Italian universities - in this sense, there are not proper differentials in terms of allocative efficiency, whilst there is clear difference in the ratio of transforming inputs' quantities into outputs (i.e. technical efficiency).

Data Envelopment Analysis (DEA) represents an appropriate method for the study of technical efficiency in this field because it is able to capture at the same time multiple inputs and outputs. Higher education has in fact a multidimensional nature and organizations working there are extremely complex. Institutions seek to achieve a wide range of targets simultaneously, trying to produce a mix of teaching and research using several resources (especially financial and human resources, both staff and students).

\subsection{DEA Model}

The DEA method is able to empirically identify the efficiency frontier highlighting the best-practices; it is a nonparametric approach, for which it is not necessary to specify a priori the shape of the production function.

The model is fully described by Zhu (2003) and Cooper et al. (2006), while its application to the higher education system is described by Johnes (2006b).

Here we can synthetically say that DEA method assumes that the efficiency of a production unit $\left(\mathrm{DMU}_{\mathrm{j}}\right)$ can be measured by calculating a weighted ratio between multiple outputs $\left(\mathrm{y}_{\mathrm{jr}}\right)$ and multiple inputs $\left(\mathrm{x}_{\mathrm{ji}}\right)$. 


$$
\max _{u, v} h_{0}(u, v)=\sum_{r} u_{r} y_{r_{0}} / \sum v_{i} x_{i_{0}}
$$

However, it is important to highlight that it measures only the relative efficiency, not the absolute; this means that the efficiency of a university is calculated with respect to the performance of other universities examined: the production units are located on the efficient frontier, while the inefficient units are below the border.

There are two different specifications of the model: input-oriented and outputoriented.

In the case of universities, we can assume an output-oriented approach: given a certain level of input, universities pursue the maximization of output. In other words, we assume that a university is not efficient if it can be shown that some other university is able to produce a greater amount of a certain output without decrease at the same time the production of the other output, and without using more resources.

The value of efficiency of the university $e_{k}$ is in the range $(0,1)$ : university $\mathrm{k}$ is efficient if the efficiency score takes the value 1 ; it is located on the efficient frontier. Consequently, an efficiency score lower than 1 implies that the university is inefficient compared to the other universities taken into account (and the magnitude of inefficiency is measured by the distance from 1).

If we assume an output-oriented approach, then inefficient universities should increase their output by a factor of $1 / e_{k}$ in order to reach the efficiency frontier.

DEA can assume constant returns to scale (CRS) or variable return to scale (VRS). The VRS assumption, used in the present study, allows instead to introduce a dimensional factor in the DEA model, so that each unit is analysed with respect to another of the same "relative" size.

The analysis is implemented with the bootstrap method "since efficiency is measured relative to an estimate of the frontier, estimates of efficiency from nonparametric models are subject to uncertainty due to sampling variation. Bootstrap methods hence, may be used to assess this uncertainty by estimating bias, confidence intervals, testing hypothesis and so on" (Daraio and Simar 2007). After the "bootstrap base" procedure, the "bias-corrected" calculation has also been implemented to correct the distortions.

Finally, we carry out a second level regression of efficiency scores (obtained through DEA model) relatively to some explanatory variables, which can be considered as "environmental" factors associated with lower levels of efficiency. The second level regression will be a Tobit one, given that Tobit regression is applied in presence of a censored variable.

Having a panel dataset, we are not only interested in the relative performance of a single university in a given year, but we also want to investigate how universities have modified their efficiency over time. To do this we apply the Malmquist index, capable of capturing changes between different years (see Johnes 2004 for a technical description). An index value $m>1$ indicates a positive growth of the production function from period $\mathrm{t}$ to period $\mathrm{t}+1$, while a value of $\mathrm{m}<1$ represents a decline. Also the index allows a decomposition of efficiency changes in two parts: one related to "pure efficiency", improvements or decline, the other measuring the structural movements of the efficiency frontier as a whole, over time. 
In order to control for sampling noise and hence verify if Malmquist indices are statistically significant, we implemented a bootstrap procedure to obtain bias-corrected estimates of Malmquist indices and their confidence intervals (Parteka and WolszczakDerlacz 2013; Simar and Wilson 1999).

To check for the statistical significance, we calculated the $(1-\alpha)$ percent confidence interval:

$$
\hat{m}_{\mathrm{i},(\mathrm{t}, \mathrm{t}+1)}+1 \_\hat{m}_{\alpha}(\mathrm{b}) \leq \mathrm{m}_{\mathrm{i},(\mathrm{t}, \mathrm{t}+1)} \leq \hat{m}_{\mathrm{i},(\mathrm{t}, \mathrm{t}+1)}+\mathrm{u} \_\hat{m}_{\alpha}(\mathrm{b})
$$

The $1 \_\hat{m}_{\alpha}$ and $\mathrm{u} \_\hat{m}_{\alpha}$ represent the lower and the upper bootstrap estimates of the confidence interval of Malmquist index, and $\alpha$ is the size of the interval. We can now define the Malmquist index as significantly different from unity if the interval defined does not include unity.

\subsection{Data}

The literature considers higher education institutions as units that, using a variety of inputs, produce a variety of outputs (Cohn et al. 1989). In order to implement the DEA model it is necessary to simplify the characteristics of the productive process. In this work universities are then identified as organizations that through the educational process "produce" graduates and through the research process "produce" financial revenues. To carry out the analysis, it is necessary define inputs and outputs of the productive process. The choice of inputs and outputs therefore requires an approximation, even if there is not in the literature a unique suggestion for the selection of adequate proxies (Johnes 2004).

Considering that one of the objectives of this paper is to analyse the Italian university system as a whole, including private universities, it has been necessary to simplify the productive process in order to allow a comparison between public and private institutions. Needing to construct a database containing comparable, complete and reliable data for both type of institution, it was not possible to consider, for example, the teaching infrastructure, because this data is not publicly available. Less parsimonious production models with administrative and technical staff, quality of research and financial resources have been tested in the robustness checks. While the general categories of inputs and outputs are quite common across studies, the choice of single indicators (as proxy for the various underlying phenomena) are always subjected to the analysts' discretionality; thus, the final results must be interpreted with caution, knowing that some details can vary when employing alternative measures. In the present study:

- as input we used the number of students, considering all typologies: 4 years degree, bachelor and masters of science, and faculty, considering all type of faculty: professors, associate professors, researchers and temporary researchers;

- the variables used as output are the number of graduates (as a proxy of the educational process) and the amount of financial resources deriving from scientific research (as a proxy of the research process). The total financial revenues from research is calculated net of clearance accounts, including third parties activities and excludes revenue by the university. 
Data were obtained, not without some difficulties in the collection derived from the absence of a single database and the non-comparability of certain data:

- from the database of the Statistical Office of the Ministry of Education with regard to students and graduates;

- from the official site of consortium CINECA for information about faculty;

- from the annual survey of Evaluation Units, conducted first for CNVSU (National Committee for Evaluation) and then for ANVUR (Italian National Agency for Evaluation), for the financial data on revenues from research.

Trying to have complete information on graduates (Monaco 2012) we decide to compute all type of graduates, and not only the regular ones; indeed these, referring to the students that have finished their educational career in terms of legal duration of the course, represent a partial measure of the educational output, because they reflect only the qualitative aspect of the process.

The efficiency analysis was then implemented on a dataset containing the values of a 5-year period: from 2007 to 2011. With regard to graduates and financial revenues we consider the calendar year; regarding students: at 2007 correspond the academic year 2006/2007; with regard to faculty: to year 2007 correspond professors at the date of December 31.

We are aware that this model is a simplified representation of reality, but in Sect. 5.2 we have analysed more complete models in order to conduct robustness checks.

As it cans see in the descriptive statistics in Table 1 data refer to 74 universities for 2007 (with 14 private universities), and 77 in 2011 (with 16 private universities). The overall data related to students, faculty and graduates show a decrease in the period examined, while revenues from research increase.

Table 1 Input and output: descriptive statistics, year 2007 and 2011

\begin{tabular}{|c|c|c|c|c|}
\hline & $\begin{array}{l}\text { Number of } \\
\text { students }\end{array}$ & $\begin{array}{l}\text { Number of } \\
\text { faculty }\end{array}$ & $\begin{array}{l}\text { Number of } \\
\text { graduates }\end{array}$ & $\begin{array}{l}\text { Revenues from } \\
\text { research }\end{array}$ \\
\hline \multicolumn{5}{|l|}{2007} \\
\hline Mean & 24,295 & 835 & 4022 & 15,125 \\
\hline Median & 16,406 & 563 & 2824 & 10,200 \\
\hline SD & 23,699 & 864 & 3781 & 17,458 \\
\hline Min & 510 & 25 & 96 & 44 \\
\hline Max & 128,125 & 4638 & 19,811 & 80,068 \\
\hline \# universities & 74 & & & \\
\hline \multicolumn{5}{|l|}{2011} \\
\hline Mean & 22,591 & 746 & 3787 & 19,452 \\
\hline Median & 15,655 & 529 & 2770 & 11,616 \\
\hline SD & 22,260 & 756 & 3710 & 27,226 \\
\hline Min & 236 & 8 & 29 & 14 \\
\hline Max & 119,126 & 4103 & 20,283 & 185,992 \\
\hline \# universities & 77 & & & \\
\hline
\end{tabular}


Table 2 Input and output: descriptive statistics by university type, year 2011

Table 3 Variable for second stage regression

\begin{tabular}{lrrrrr}
\hline & \multicolumn{1}{l}{ Public } & & & Private & \\
\cline { 2 - 3 } \cline { 6 - 6 } & Mean & SD & & Mean & SD \\
\hline Number of students & 26,911 & 22,646 & & 6123 & 9327 \\
Number of faculty & 896 & 764 & 172 & 330 \\
Number of graduates & 4404 & 3784 & & 1436 & 2157 \\
Revenues from research & 23,524 & 29,074 & & 3930 & 6365 \\
\# universities & & 61 & & 16 \\
\hline
\end{tabular}

\begin{tabular}{lccc}
\hline & Public & Private & Total \\
\hline 2007 & & & \\
North & 22 & 7 & 29 \\
Centre & 15 & 4 & 19 \\
South & 23 & 3 & 26 \\
With medicine's courses & 37 & 3 & 40 \\
Revenues from fees' mean (\%) & 8.5 & 30.2 & 12.9 \\
Foreign students (\%) & 1.5 & 1.3 & 1.5 \\
BA/MA students & 3.4 & 5.8 & 3.9 \\
2011 & & & \\
North & 22 & 8 & 30 \\
Centre & 16 & 4 & 20 \\
South & 23 & 4 & 27 \\
With medicine's courses & 37 & 3 & 40 \\
Revenues from fees' mean (2010) (\%) & 9.4 & 35.0 & 14.5 \\
Foreign students (\%) & 2.0 & 2.6 & 2.1 \\
BA/MA students & 2.2 & 3.1 & 2.3 \\
\hline
\end{tabular}

Descriptive statistics on the type of university (public-private, in Table 2) show that private universities are generally much smaller than public ones.

For the second stage regression in which we explore the determinants of efficiency scores, we have also used additional variables, ${ }^{8}$ presented in Table 3:

- two dummy variables for universities located in Central and Southern Italy;

- a dummy variable indicating the presence of medical courses in the university (medicine courses are normally associated with higher unit costs);

- a variable indicating the share of revenues from students' fees with respect to the total revenues of the university (the idea is to investigate whether universities which are more funding related to students do have to operate more efficient, or not), as a proxy for the incentive to improve efficiency responding to student's pressure;

\footnotetext{
8 Obviously, some of these variables can be considered as not completely exogenous, and partially affected through choices realised by each institution. In this sense, our analysis is purely descriptive, and can provide information about statistical correlations, not causal relationships.
} 
- a variable indicating the share of foreign students, to investigate whether the competition also on international scale (to attract more foreign students) and an international orientation improve efficiency;

- a variable indicating the proportion of BA students over MA students, to control if the orientation of the institution for bachelor programs can affect efficiency.

\section{Results}

\subsection{Efficiency Scores of Universities: An Overview}

In Table 4 efficiency scores obtained through the implementation of the basic DEA model obtained for all single years are shown, in which as input are considered the total number of students and professors and as output the total number of graduates and the revenues from scientific research.

There are universities very stable in all years, with efficiency values steadily in the first quartile, and universities steadily less efficient. The results appear to be consistent with previous studies. Comparing the scores for year 2008 with the analysis made by Monaco (2012) on the same academic year, it could be noted that the universities that in this research appear as the most efficient (Padova, Bologna and Siena between the publics; Università Cattolica del Sacro Cuore and Università Luigi Bocconi between the private ones) show high efficiency scores also in Monaco's work.

For ease of reading, Tables 5, 6 and 7 show some summary statistics obtained by grouping universities analysed by type (public and private), and geographical location (North, Centre, South).

These results (reported also graphically in Fig. 3) reveal that private universities are on average relatively more efficient than the public ones, and this (relative) differential seems to increase in the years analysed: when considering the geographical area, the results show a greater efficiency of Northern universities than the central and even more the Southern ones. Finally, combining the type of the university and the geographical area it can be observed that, while among public universities the most efficient are located in the North; among private universities efficiency is greater for those in central Italy.

In Fig. 4 are finally represented the efficiency scores of year 2011 for all universities; universities above the horizontal line, which represents the total average, are relatively more efficient.

\subsection{Efficiency Scores of Universities: Robustness Checks}

In order to verify the robustness of the model, in Table 8 are reported the Pearson correlation indexes between the base model (implemented with bootstrap method and 200 repetitions) and other alternative specifications of the model itself: ${ }^{9}$

\footnotetext{
9 Reading the Table 8, it can be noted that we calculated the efficiency scores also for some models where only one input and one output at a time are employed. Indeed, while one of the strength of DEA is dealing with multiple inputs and outputs, we also consider the one input/one output settings to check the consistency of results across all the various potential specifications-including the simplest ones.
} 
Table 4 Efficiency scores, by university and year

\begin{tabular}{|c|c|c|c|c|c|c|}
\hline University & Type & 2007 & 2008 & 2009 & 2010 & 2011 \\
\hline Aosta: Università degli studi & Private & 0.606 & 0.409 & 0.380 & 0.475 & 0.450 \\
\hline Bolzano: Libera Università & Private & 0.388 & 0.612 & 0.619 & 0.639 & 0.731 \\
\hline Bra: Università di Scienze Gastronomiche & Private & n.d. & n.d. & n.d. & n.d. & 0.771 \\
\hline Casamassima: Libera Università "Jean Monnet" & Private & 0.596 & 0.508 & 0.747 & 0.586 & 0.525 \\
\hline Castellanza: Università "Carlo Cattaneo" & Private & 0.785 & 0.759 & 0.775 & 0.866 & 0.908 \\
\hline Enna: Università “KORE" & Private & 0.562 & 0.490 & 0.421 & 0.481 & 0.481 \\
\hline $\begin{array}{l}\text { Milano: Libera Università di Lingue e Comunicazione } \\
\text { (IULM) }\end{array}$ & Private & 0.733 & 0.776 & 0.802 & 0.767 & 0.692 \\
\hline Milano: Università Cattolica del "Sacro Cuore" & Private & 0.857 & 0.808 & 0.867 & 0.915 & 0.893 \\
\hline Milano: Università commerciale "Luigi Bocconi" & Private & 0.817 & 0.822 & 0.843 & 0.856 & 0.848 \\
\hline Milano: Università Vita-Salute San Raffaele & Private & 0.807 & 0.838 & 0.835 & 0.888 & 0.859 \\
\hline Napoli: Istituto "Suor Orsola Benincasa" & Private & 0.836 & 0.855 & 0.843 & 0.809 & 0.856 \\
\hline Reggio Calabria: Università "Dante Alighieri” & Private & n.d. & n.d. & n.d. & 0.773 & 0.773 \\
\hline Roma: LUISS & Private & 0.599 & 0.812 & 0.827 & 0.795 & 0.780 \\
\hline Roma: LUMSA & Private & 0.856 & 0.819 & 0.839 & 0.652 & 0.677 \\
\hline Roma: UNINT & Private & 0.790 & 0.764 & 0.765 & 0.739 & 0.885 \\
\hline Roma: Università "Campus Bio-Medico" & Private & 0.799 & 0.770 & 0.755 & 0.760 & 0.769 \\
\hline Ancona: Università Politecnica delle Marche & Public & 0.604 & 0.531 & 0.547 & 0.512 & 0.535 \\
\hline Arcavacata di Rende: Università della Calabria & Public & 0.586 & 0.611 & 0.663 & 0.667 & 0.698 \\
\hline Bari: Politecnico & Public & 0.762 & 0.433 & 0.553 & 0.332 & 0.522 \\
\hline Bari: Università degli studi & Public & 0.671 & 0.678 & 0.689 & 0.725 & 0.728 \\
\hline Benevento: Università degli studi del Sannio & Public & 0.613 & 0.720 & 0.553 & 0.322 & 0.450 \\
\hline Bergamo: Università degli studi & Public & 0.470 & 0.450 & 0.542 & 0.507 & 0.519 \\
\hline Bologna: Università degli studi & Public & 0.874 & 0.841 & 0.869 & 0.846 & 0.873 \\
\hline Brescia: Università degli studi & Public & 0.516 & 0.511 & 0.474 & 0.480 & 0.504 \\
\hline Cagliari: Università degli studi & Public & 0.460 & 0.459 & 0.507 & 0.531 & 0.562 \\
\hline Camerino: Università degli studi & Public & 0.343 & 0.421 & 0.467 & 0.412 & $\mathbf{0 . 4 3 7}$ \\
\hline Campobasso: Università degli studi del Molise & Public & 0.397 & 0.388 & 0.366 & 0.381 & 0.609 \\
\hline Cassino: Università degli studi & Public & 0.388 & 0.370 & 0.429 & 0.377 & 0.414 \\
\hline Catania: Università degli studi & Public & 0.758 & 0.661 & 0.808 & 0.732 & 0.733 \\
\hline Catanzaro: Università degli studi "Magna Grecia" & Public & 0.519 & 0.498 & 0.513 & 0.477 & 0.429 \\
\hline Chieti: Università degli studi D’Annunzio & Public & 0.855 & 0.948 & 0.859 & 0.725 & 0.828 \\
\hline Ferrara: Università degli studi & Public & 0.605 & 0.461 & 0.489 & 0.510 & 0.551 \\
\hline Firenze: Università degli studi & Public & 0.786 & 0.856 & 0.863 & 0.737 & 0.773 \\
\hline Foggia: Università degli studi & Public & 0.488 & 0.446 & 0.387 & 0.401 & 0.382 \\
\hline Genova: Università degli studi & Public & 0.808 & 0.686 & 0.611 & 0.620 & 0.617 \\
\hline L'Aquila: Università degli studi & Public & 0.613 & 0.522 & 0.566 & 0.564 & 0.565 \\
\hline Lecce: Università degli studi & Public & 0.738 & 0.587 & 0.637 & 0.628 & 0.788 \\
\hline Macerata: Università degli studi & Public & 0.470 & 0.439 & 0.553 & 0.452 & 0.501 \\
\hline Messina: Università degli studi & Public & 0.537 & 0.488 & 0.491 & 0.539 & 0.524 \\
\hline Milano: Politecnico & Public & 0.870 & 0.859 & 0.832 & 0.816 & 0.798 \\
\hline
\end{tabular}


Table 4 continued

\begin{tabular}{|c|c|c|c|c|c|c|}
\hline University & Type & 2007 & 2008 & 2009 & 2010 & 2011 \\
\hline Milano: Università degli studi & Public & 0.821 & 0.784 & 0.696 & 0.733 & 0.727 \\
\hline Milano-Bicocca: Università degli studi & Public & 0.707 & 0.662 & 0.724 & 0.659 & 0.757 \\
\hline Modena e Reggio Emilia: Università degli studi & Public & 0.803 & 0.667 & 0.607 & 0.738 & 0.680 \\
\hline Napoli: Seconda Università degli studi & Public & 0.571 & 0.492 & 0.516 & 0.576 & 0.559 \\
\hline Napoli: Università degli studi "Federico II" & Public & 0.740 & 0.717 & 0.689 & 0.748 & 0.778 \\
\hline Napoli: Università degli studi “L' Orientale" & Public & 0.526 & 0.462 & 0.595 & 0.493 & 0.536 \\
\hline Napoli: Università degli studi "Parthenope" & Public & 0.490 & 0.417 & 0.477 & 0.457 & 0.428 \\
\hline Padova: Università degli studi & Public & 0.906 & 0.852 & 0.884 & 0.866 & 0.869 \\
\hline Palermo: Università degli studi & Public & 0.776 & 0.652 & 0.614 & 0.660 & 0.735 \\
\hline Parma: Università degli studi & Public & 0.656 & 0.577 & 0.602 & 0.619 & 0.634 \\
\hline Pavia: Università degli studi & Public & 0.831 & 0.613 & 0.603 & 0.654 & 0.650 \\
\hline Perugia: Università degli studi & Public & 0.742 & 0.544 & 0.736 & 0.617 & 0.622 \\
\hline Perugia: Università per stranieri & Public & 0.664 & 0.801 & 0.748 & 0.736 & 0.814 \\
\hline Pisa: Università degli studi & Public & 0.635 & 0.647 & 0.640 & 0.638 & 0.613 \\
\hline Potenza: Università degli studi della Basilicata & Public & 0.436 & 0.378 & 0.298 & 0.353 & 0.375 \\
\hline Reggio Calabria: Università Mediterranea & Public & 0.330 & 0.319 & 0.366 & 0.314 & 0.351 \\
\hline Roma: III Università degli studi & Public & 0.693 & 0.775 & 0.776 & 0.794 & 0.730 \\
\hline Roma: Università degli studi "La Sapienza" & Public & 0.816 & 0.802 & 0.782 & 0.785 & 0.784 \\
\hline Roma: Università degli studi del "Foro Italico" & Public & n.d. & 0.402 & 0.473 & 0.743 & 0.614 \\
\hline Roma: Università degli studi di “Tor Vergata" & Public & 0.573 & 0.566 & 0.540 & 0.593 & 0.532 \\
\hline Salerno: Università degli studi & Public & 0.548 & 0.562 & 0.589 & 0.595 & 0.528 \\
\hline Sassari: Università degli studi & Public & 0.430 & 0.497 & 0.386 & 0.453 & 0.484 \\
\hline Siena: Università degli studi & Public & 0.936 & 0.876 & 0.864 & 0.643 & 0.670 \\
\hline Siena: Università per stranieri & Public & 0.783 & 0.775 & 0.753 & 0.620 & 0.678 \\
\hline Teramo: Università degli studi & Public & 0.425 & 0.383 & 0.353 & 0.355 & 0.398 \\
\hline Torino: Politecnico & Public & 0.832 & 0.810 & 0.848 & 0.777 & 0.864 \\
\hline Torino: Università degli studi & Public & 0.883 & 0.888 & 0.811 & 0.907 & 0.831 \\
\hline Trento: Università degli studi & Public & 0.917 & 0.556 & 0.561 & 0.579 & 0.568 \\
\hline Trieste: Università degli studi & Public & 0.667 & 0.642 & 0.571 & 0.594 & 0.579 \\
\hline Udine: Università degli studi & Public & 0.598 & 0.748 & 0.617 & 0.645 & 0.631 \\
\hline Urbino: Università degli studi & Public & 0.609 & 0.538 & 0.601 & 0.575 & 0.573 \\
\hline Varese: Università dell' Insubria & Public & 0.453 & 0.518 & 0.477 & 0.553 & 0.500 \\
\hline Venezia: Università degli studi “Cà Foscari” & Public & 0.629 & 0.594 & 0.650 & 0.662 & 0.678 \\
\hline Venezia: Università IUAV & Public & 0.671 & 0.709 & 0.842 & 0.800 & 0.775 \\
\hline Vercelli: Università del Piemonte orientale & Public & 0.659 & 0.626 & 0.555 & 0.602 & 0.578 \\
\hline Verona: Università degli studi & Public & 0.563 & 0.528 & 0.593 & 0.632 & 0.604 \\
\hline Viterbo: Università della Tuscia & Public & 0.818 & 0.727 & 0.807 & 0.666 & 0.724 \\
\hline
\end{tabular}

The analysis have been implemented through "FEAR" package by R: Wilson (2008)

Italic values represent first quartile, bold values represent forth quartile 
Table 5 Efficiency scores' statistics by university's type

Table 6 Efficiency scores' statistics by geographical area

\begin{tabular}{cccccc}
\hline & 2007 & 2008 & 2009 & 2010 & 2011 \\
\hline Total & & & & & \\
Mean & 0.661 & 0.627 & 0.638 & 0.628 & 0.645 \\
SD & 0.156 & 0.160 & 0.157 & 0.152 & 0.147 \\
Private & & & & & \\
Mean & 0.716 & 0.717 & 0.737 & 0.733 & 0.744 \\
SD & 0.136 & 0.142 & 0.150 & 0.134 & 0.141 \\
Public & & & & & \\
Mean & 0.648 & 0.606 & 0.615 & 0.602 & 0.619 \\
SD & 0.158 & 0.156 & 0.149 & 0.145 & 0.137 \\
\hline
\end{tabular}

\begin{tabular}{cccccc}
\hline & 2007 & 2008 & 2009 & 2010 & 2011 \\
\hline $\begin{array}{l}\text { Total } \\
\text { Mean }\end{array}$ & 0.661 & 0.627 & 0.638 & 0.628 & 0.645 \\
SD & 0.156 & 0.160 & 0.157 & 0.152 & 0.147 \\
North & & & & & \\
Mean & 0.715 & 0.676 & 0.675 & 0.697 & 0.698 \\
SD & 0.145 & 0.136 & 0.143 & 0.134 & 0.133 \\
Centre & & & & & \\
Mean & 0.679 & 0.662 & 0.688 & 0.642 & 0.656 \\
SD & 0.156 & 0.164 & 0.139 & 0.123 & 0.126 \\
South & & & & & \\
Mean & 0.587 & 0.545 & 0.557 & 0.544 & 0.579 \\
SD & 0.140 & 0.148 & 0.153 & 0.149 & 0.150 \\
\hline
\end{tabular}

- the implementation of the model with 1000 or 1500 repetitions (DEA2 and DEA3) leads to the same results captured by the base model, showing a correlation index close to 1 ;

- the implementation of separate models for teaching (DEA4) and research (DEA5) shows a higher correlation with the base model and the model relative to teaching, highlighting a greater explanatory power of these variables;

- the introduction of the variable "revenues from research for each professor" to replace the variable "revenues from research" (DEA6) shows a relatively high correlation with the base model;

- the analysis of two separate models for BA students (DEA7) and MA students (DEA8) show a very strong correlation for the former, indicating a stronger explanatory power of the data related to students and graduates of the bachelor courses;

- as shown in Table 8, the correlation of the model with a model without revenues from research as output (DEA9) is relatively high, with a value varying from 0.382 for year 2011 to 0.579 for year 2007 . 
Table 7 Statistics on efficiency scores by type of university and geographical area

\begin{tabular}{lll}
\hline 2007 & Private & Public \\
\hline North & & \\
Mean & 0.713 & 0.715 \\
SD & 0.153 & 0.142
\end{tabular}

Centre

$\begin{array}{lll}\text { Mean } & 0.761 & 0.657 \\ \text { SD } & 0.097 & 0.161\end{array}$

South

\begin{tabular}{lll} 
Mean & 0.665 & 0.577 \\
SD & 0.122 & 0.139 \\
\hline 2008 & Private & Public \\
\hline North & & \\
Mean & 0.718 & 0.663 \\
SD & 0.144 & 0.131 \\
Centre & & \\
Mean & 0.791 & 0.629 \\
SD & 0.024 & 0.168
\end{tabular}

South

Mean $0.618 \quad 0.536$

$\begin{array}{lll}\text { SD } & 0.168 & 0.142\end{array}$

\begin{tabular}{lll}
\hline 2009 & Private & Public \\
\hline North & & \\
Mean & 0.732 & 0.657 \\
SD & 0.163 & 0.131
\end{tabular}

Centre

$\begin{array}{lll}\text { Mean } & 0.797 & 0.661 \\ \text { SD } & 0.037 & 0.142\end{array}$

South

\begin{tabular}{ccc} 
Mean & 0.670 & 0.542 \\
SD & 0.180 & 0.142 \\
\hline 2010 & Private & Public \\
\hline North & & \\
Mean & 0.772 & 0.673 \\
SD & 0.149 & 0.119
\end{tabular}

Centre

$\begin{array}{lll}\text { Mean } & 0.737 & 0.619 \\ \text { SD } & 0.053 & 0.124\end{array}$

South

\begin{tabular}{lll} 
Mean & 0.662 & 0.523 \\
$\mathrm{SD}$ & 0.134 & 0.142 \\
\hline
\end{tabular}


Table 7 continued

\begin{tabular}{lll}
\hline 2011 & Private & Public \\
\hline North & & \\
Mean & 0.769 & 0.672 \\
SD & 0.141 & 0.119 \\
Centre & & \\
Mean & 0.778 & 0.626 \\
SD & 0.074 & 0.118 \\
South & & \\
Mean & 0.659 & 0.565 \\
SD & 0.159 & 0.144 \\
\hline
\end{tabular}

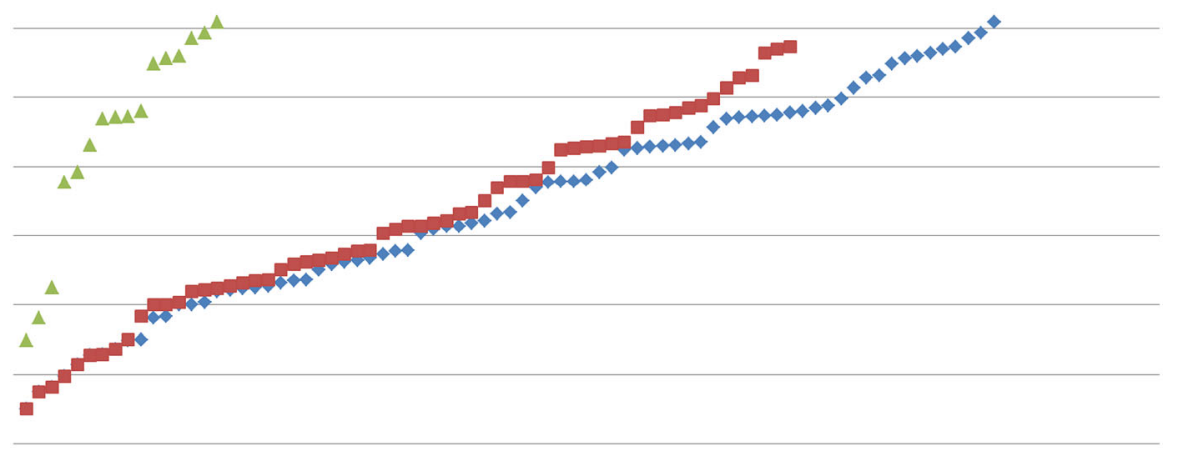

Fig. 3 Efficiency scores, year 2011

In order to check the robustness of the model, we integrated our dataset and we estimated new DEA models, less parsimonious of our baseline, in which the set of variable included in the productive process is "augmented". 10

Knowing that faculty only represent a portion of the total persons working in universities, in the first specification of the model we included in the set of inputs administrative and technical staff, both tenured and untenured. ${ }^{11}$ The productive process behind the model considers is therefore students, faculty and administrative staff as inputs, graduates and revenues from research as outputs. The results are

10 Due to space limits, we are not able to report all the indices for every HEI analyzed. The list of scores is available upon request.

11 Data have been obtained from the annual survey of Evaluation Units. 


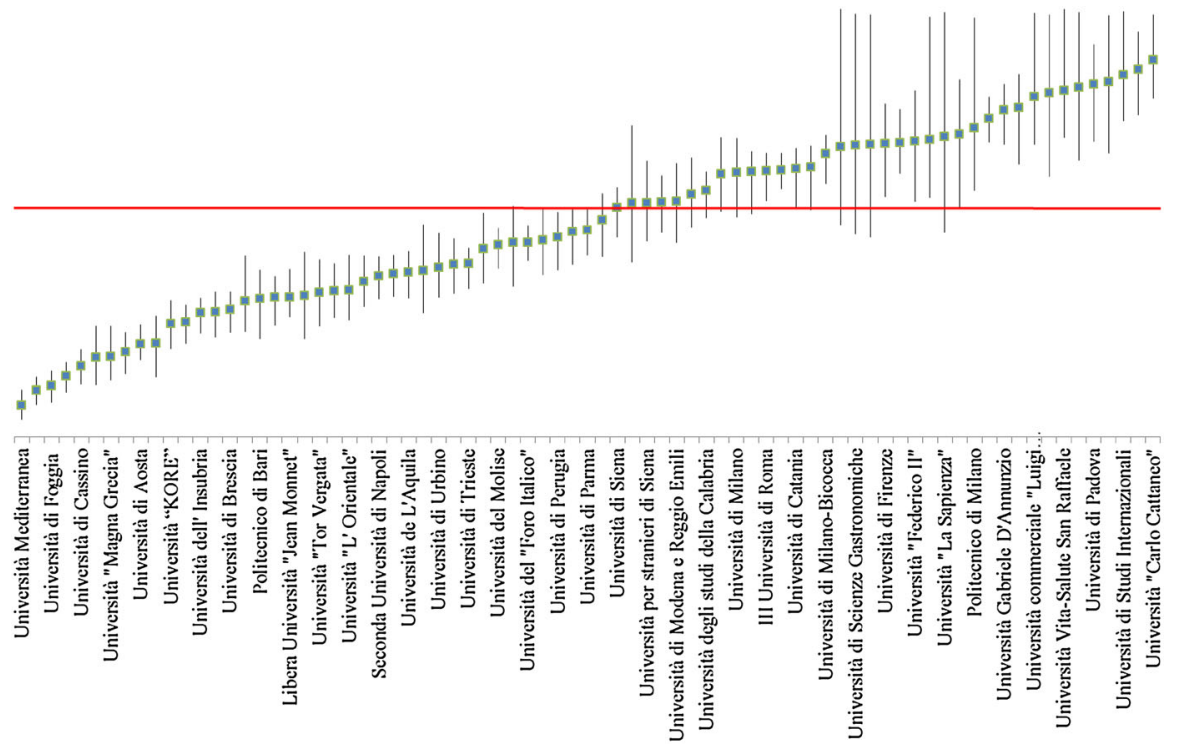

Fig. 4 Efficiency scores' (bias corrected values and confidence intervals), year 2011

Table 8 Pearson correlation indexes: efficiency scores obtained through different DEA models, by year

\begin{tabular}{llllllllll}
\hline 2007 & DEAbase & DEA2 & DEA3 & DEA4 & DEA5 & DEA6 & DEA7 & DEA8 & DEA9 \\
\hline DEAbase & 1 & 1.000 & 1.000 & 0.720 & 0.542 & 0.543 & 0.926 & 0.661 & 0.579 \\
DEA2 & 1.000 & 1 & 1.000 & 0.724 & 0.543 & 0.542 & 0.928 & 0.661 & 0.581 \\
DEA3 & 1.000 & 1.000 & 1 & 0.723 & 0.544 & 0.542 & 0.927 & 0.661 & 0.581 \\
DEA4 & 0.720 & 0.724 & 0.723 & 1 & 0.186 & 0.468 & 0.707 & 0.374 & 0.211 \\
DEA5 & 0.542 & 0.543 & 0.544 & 0.186 & 1 & 0.114 & 0.606 & 0.581 & 0.942 \\
DEA6 & 0.543 & 0.542 & 0.542 & 0.468 & 0.114 & 1 & 0.440 & 0.279 & 0.091 \\
DEA7 & 0.926 & 0.928 & 0.927 & 0.707 & 0.606 & 0.440 & 1 & 0.662 & 0.650 \\
DEA8 & 0.661 & 0.661 & 0.661 & 0.374 & 0.581 & 0.279 & 0.662 & 1 & 0.630 \\
DEA9 & 0.579 & 0.581 & 0.581 & 0.211 & 0.942 & 0.091 & 0.650 & 0.630 & 1 \\
\hline 2008 & DEAbase & DEA2 & DEA3 & DEA4 & DEA5 & DEA6 & DEA7 & DEA8 & DEA9 \\
\hline DEAbase & 1 & 1.000 & 1.000 & 0.835 & 0.503 & 0.762 & 0.889 & 0.75 & 0.562 \\
DEA2 & 1.000 & 1 & 1 & 0.838 & 0.503 & 0.761 & 0.889 & 0.748 & 0.562 \\
DEA3 & 1.000 & 1.000 & 1 & 0.837 & 0.505 & 0.762 & 0.889 & 0.748 & 0.562 \\
DEA4 & 0.835 & 0.838 & 0.837 & 1 & 0.417 & 0.666 & 0.773 & 0.715 & 0.506 \\
DEA5 & 0.503 & 0.503 & 0.505 & 0.417 & 1 & 0.319 & 0.467 & 0.624 & 0.921 \\
DEA6 & 0.762 & 0.761 & 0.762 & 0.666 & 0.319 & 1 & 0.687 & 0.524 & 0.343 \\
DEA7 & 0.889 & 0.889 & 0.889 & 0.773 & 0.467 & 0.687 & 1 & 0.691 & 0.535 \\
DEA8 & 0.750 & 0.748 & 0.748 & 0.715 & 0.624 & 0.524 & 0.691 & 1 & 0.683 \\
DEA9 & 0.562 & 0.562 & 0.562 & 0.506 & 0.921 & 0.343 & 0.535 & 0.683 & 1 \\
\hline
\end{tabular}


Table 8 continued

\begin{tabular}{|c|c|c|c|c|c|c|c|c|c|}
\hline 2009 & DEAbase & DEA2 & DEA3 & DEA4 & DEA5 & DEA6 & DEA7 & DEA8 & DEA9 \\
\hline DEAbase & 1 & 1.000 & 1.000 & 0.876 & 0.503 & 0.663 & 0.928 & 0.729 & 0.517 \\
\hline DEA2 & 1.000 & 1 & 1.000 & 0.874 & 0.503 & 0.665 & 0.929 & 0.732 & 0.516 \\
\hline DEA3 & 1.000 & 1.000 & 1 & 0.873 & 0.501 & 0.664 & 0.929 & 0.73 & 0.514 \\
\hline DEA4 & 0.876 & 0.874 & 0.873 & 1 & 0.522 & 0.598 & 0.791 & 0.712 & 0.550 \\
\hline DEA5 & 0.503 & 0.503 & 0.501 & 0.522 & 1 & 0.330 & 0.521 & 0.569 & 0.989 \\
\hline DEA6 & 0.663 & 0.665 & 0.664 & 0.598 & 0.330 & 1 & 0.594 & 0.697 & 0.329 \\
\hline DEA7 & 0.928 & 0.929 & 0.929 & 0.791 & 0.521 & 0.594 & 1 & 0.671 & 0.533 \\
\hline DEA8 & 0.729 & 0.732 & 0.730 & 0.712 & 0.569 & 0.697 & 0.671 & 1 & 0.559 \\
\hline DEA9 & 0.517 & 0.516 & 0.514 & 0.550 & 0.989 & 0.329 & 0.533 & 0.559 & 1 \\
\hline 2010 & DEAbase & DEA2 & DEA3 & DEA4 & DEA5 & DEA6 & DEA7 & DEA8 & DEA9 \\
\hline DEAbase & 1 & 1.000 & 1.000 & 0.911 & 0.571 & 0.771 & 0.911 & 0.832 & 0.565 \\
\hline DEA2 & 1.000 & 1 & 1.000 & 0.91 & 0.572 & 0.773 & 0.91 & 0.831 & 0.567 \\
\hline DEA3 & 1.000 & 1.000 & 1 & 0.909 & 0.772 & 0.773 & 0.91 & 0.831 & 0.567 \\
\hline DEA4 & 0.911 & 0.910 & 0.909 & 1 & 0.543 & 0.703 & 0.861 & 0.83 & 0.533 \\
\hline DEA5 & 0.571 & 0.572 & 0.772 & 0.543 & 1 & 0.468 & 0.505 & 0.519 & 0.987 \\
\hline DEA6 & 0.771 & 0.773 & 0.773 & 0.703 & 0.468 & 1 & 0.732 & 0.635 & 0.461 \\
\hline DEA7 & 0.911 & 0.910 & 0.910 & 0.861 & 0.505 & 0.732 & 1 & 0.709 & 0.503 \\
\hline DEA8 & 0.832 & 0.831 & 0.831 & 0.830 & 0.519 & 0.635 & 0.709 & 1 & 0.503 \\
\hline DEA9 & 0.565 & 0.567 & 0.567 & 0.533 & 0.987 & 0.461 & 0.503 & 0.503 & 1 \\
\hline 2011 & DEAbase & DEA2 & DEA3 & DEA4 & DEA5 & DEA6 & DEA7 & DEA8 & DEA9 \\
\hline DEAbase & 1 & 1 & 1 & 0.811 & 0.386 & 0.787 & 0.893 & 0.821 & 0.382 \\
\hline DEA2 & 1.000 & 1 & 1 & 0.809 & 0.384 & 0.787 & 0.892 & 0.823 & 0.379 \\
\hline DEA3 & 1.000 & 1.000 & 1 & 0.809 & 0.386 & 0.788 & 0.891 & 0.823 & 0.381 \\
\hline DEA4 & 0.811 & 0.809 & 0.809 & 1 & 0.281 & 0.625 & 0.753 & 0.689 & 0.288 \\
\hline DEA5 & 0.386 & 0.384 & 0.386 & 0.281 & 1 & 0.354 & 0.41 & 0.514 & 0.986 \\
\hline DEA6 & 0.787 & 0.787 & 0.788 & 0.625 & 0.354 & 1 & 0.692 & 0.676 & 0.341 \\
\hline DEA7 & 0.893 & 0.892 & 0.891 & 0.753 & 0.410 & 0.692 & 1 & 0.701 & 0.417 \\
\hline DEA8 & 0.821 & 0.823 & 0.823 & 0.689 & 0.514 & 0.676 & 0.701 & 1 & 0.502 \\
\hline DEA9 & 0.382 & 0.379 & 0.381 & 0.288 & 0.986 & 0.341 & 0.417 & 0.502 & 1 \\
\hline
\end{tabular}

$D E A 2$ same variables of the base model with 1000 repetitions; DEA3 same variables of the base model with 1500 repetitions; DEA4 input $=$ total students, output $=$ total graduates; DEA5 input $=$ total faculty, output $=$ revenues from research; DEA6 input $=$ total students and total faculty, output $=$ total graduates and revenues from research for single professor; $D E A 7$ input $=\mathrm{BA}$ students and total faculty, output $=\mathrm{BA}$ graduates and revenues from research for single professor; DEA 8 input = MA students and total faculty, output = MA graduates and revenues from research for single professor; DEA9 input $=$ total students and total faculty, output $=$ total graduates

summarized in Table 9, where it is possible to notice that the efficiency scores are quantitatively and qualitatively very similar, with better scores for private universities, and the correlation indexes are very high, always higher than 0.91 . 
Table 9 DEA model "DEAa" with inputs: students, faculty, administrative staff; outputs: graduates, revenues from research

\begin{tabular}{llllll}
\hline DEAa & $\begin{array}{l}\text { Mean } \\
\text { efficiency } \\
2007\end{array}$ & $\begin{array}{l}\text { Mean } \\
\text { efficiency } \\
2008\end{array}$ & $\begin{array}{l}\text { Mean } \\
\text { efficiency } \\
2009\end{array}$ & $\begin{array}{l}\text { Mean } \\
\text { efficiency } \\
2010\end{array}$ & $\begin{array}{l}\text { Mean } \\
\text { efficiency } \\
2011\end{array}$ \\
\hline $\begin{array}{l}\text { Private } \\
\text { Public }\end{array}$ & 0.757 & 0.742 & 0.736 & 0.757 & 0.768 \\
Total & 0.659 & 0.607 & 0.616 & 0.614 & 0.627 \\
\hline $\begin{array}{l}\text { Pearson correlation } \\
\text { indexes }\end{array}$ & 0.677 & 0.632 & 0.639 & 0.642 & 0.656 \\
\hline DEAbase/DEAa & 2007 & 2008 & 2009 & 2010 & 2011 \\
\hline
\end{tabular}

Mean of efficiency scores by type of university and Pearson correlation indexes

Table 10 DEA model "DEAb" with inputs: students, faculty, administrative staff, total spending; outputs: graduates, revenues from research

\begin{tabular}{lllll}
\hline DEAb & $\begin{array}{l}\text { Mean } \\
\text { efficiency } \\
2007\end{array}$ & $\begin{array}{l}\text { Mean } \\
\text { efficiency } \\
2008\end{array}$ & $\begin{array}{l}\text { Mean } \\
\text { efficiency } \\
2009\end{array}$ & $\begin{array}{l}\text { Mean } \\
\text { efficiency } \\
2010\end{array}$ \\
\hline Private & 0.782 & 0.797 & 0.812 & 0.801 \\
Public & 0.710 & 0.703 & 0.716 & 0.702 \\
Total & 0.724 & 0.720 & 0.734 & 0.722 \\
\hline $\begin{array}{l}\text { Pearson correlation } \\
\text { indexes }\end{array}$ & 2007 & 2008 & 2009 & 2010 \\
\hline
\end{tabular}

DEAbase/DEAb

0.852

0.755

0.814

0.769

Mean of efficiency scores by type of university and Pearson correlation indexes

Another important factor to consider in the productive process is the financial aspect; for this reason we included in our analysis the total spending. We estimated a model that include among inputs students, academic staff, administrative staff and total spending. However, data is not available for 2011, so the model is estimated only for years that are available: 2007, 2008, 2009 and 2010. ${ }^{12}$

As shown in Table 10, the efficiency scores are similar, with the differential between private and public universities high. In addition, the correlations between the new model and the baseline one are very high (always higher than 0.75).

Finally, we tried to include in the model not only a proxy for the quantity of research, but also for the quality of research. To do so we separated our original variable "Revenues from research" in two indicators: (i) grants from competitive sources (we identified them as transfers from Ministry of Education and European Union) and (ii) other revenues from research, using a characteristic of the balance sheets' classifications for this purpose. ${ }^{13}$ We then estimated a new DEA model, where inputs

\footnotetext{
12 Data have been obtained from the annual survey of Evaluation Units.

13 Data have been obtained from the annual survey of Evaluation Units.
} 
Table 11 DEA model "DEAc" with inputs: students, faculty, administrative staff, total spending; outputs: graduates, grants from competitive sources, and other revenues from research

\begin{tabular}{lllll}
\hline DEAc & $\begin{array}{l}\text { Mean } \\
\text { efficiency } \\
2007\end{array}$ & $\begin{array}{l}\text { Mean } \\
\text { efficiency } \\
2008\end{array}$ & $\begin{array}{l}\text { Mean } \\
\text { efficiency } \\
2009\end{array}$ & $\begin{array}{l}\text { Mean } \\
\text { efficiency } \\
2010\end{array}$ \\
\hline Private & 0.795 & 0.801 & 0.809 & 0.812 \\
Public & 0.726 & 0.702 & 0.721 & 0.711 \\
Total & 0.740 & 0.721 & 0.737 & 0.731 \\
\hline Pearson correlation indexes & 2007 & 2008 & 2009 & 2010 \\
\hline DEAbase/DEAc & 0.855 & 0.747 & 0.817 & 0.784 \\
\hline
\end{tabular}

Mean of efficiency scores by type of university and Pearson correlation indexes

are: students, academic staff, administrative staff and total expenditure; and outputs are: graduates, grants from competitive sources, and other revenues from research. The results, reported in Table 11, show that the correlations between the new model and the baseline one are very high (higher than 0.74) and the efficiency scores very similar, with better results for private universities.

We finally decided to check how our baseline results would be affected by the exclusion of some small universities, i.e. universities in which the number of students is below 3500. ${ }^{14}$ In this case, the "restricted sample" is of 7 (out of 16 of year 2011) private universities, and 58 (out of 61 of year 2011) public universities. ${ }^{15}$ The new results from DEA, not included here due to space limits but available upon request, reveal that difference in the institutions' size is not a major factor that affects efficiency results: efficiency scores are quite similar and also in this case better for private universities, and correlation indices very high (always higher than 0.87 ).

\subsection{The Evolution of Universities' Efficiency Over Time: An Analysis Based on Malmquist Index}

The analysis over the years has been conducted through the calculation of the Malmquist index (Table 12), which highlights the changes in efficiency over the years. The Malmquist index can be decomposed into two components:

- a component that indicates the efficiency change, or that describes the ability of the institutions to produce their output, given their input, with a certain technology;

- a component linked instead to the "change in the efficiency frontier" (frontier shift), which indicates changes in productivity achieved thanks to improved "technology".

\footnotetext{
14 We are grateful to one reviewer for this suggestion.

15 Private universities excluded from the sample are: Aosta, Bolzano, Bra, Casamassima "Jean Monnet", Castellanza, Milano San Raffaele, Università per Stranieri "Dante Alighieri”, Roma UNINT e Roma "Campus Bio-Medico". Public universities, that were excluded from the sample, are: Perugia - Università per stranieri, Università del "Foro Italico" and Siena - Università per stranieri.
} 
Table 12 Malmquist index

\begin{tabular}{|c|c|c|c|c|c|}
\hline University & Type & Area & $\begin{array}{l}\text { Malmquist } \\
\text { index }\end{array}$ & $\begin{array}{l}\text { Efficiency } \\
\text { change }\end{array}$ & $\begin{array}{l}\text { Frontier } \\
\text { shift }\end{array}$ \\
\hline Aosta: Università degli studi & Private & North & 0.954 & 0.996 & 0.957 \\
\hline Bolzano: Libera Università & Private & North & 1.250 & 1.783 & 0.701 \\
\hline Casamassima: Università "Jean Monnet" & Private & South & 0.644 & 0.890 & 0.723 \\
\hline Castellanza: Università "Carlo Cattaneo" & Private & North & 0.878 & 0.972 & 0.904 \\
\hline Milano: Libera Università IULM & Private & North & 0.950 & 1.537 & 0.618 \\
\hline Milano: Università Cattolica del "Sacro Cuore" & Private & North & 1.062 & 0.000 & 0.768 \\
\hline $\begin{array}{l}\text { Milano: Università commerciale } \\
\text { "Luigi Bocconi" }\end{array}$ & Private & North & 0.991 & 1.000 & 0.991 \\
\hline Milano: Università Vita-Salute San Raffaele & Private & North & 1.166 & 1.000 & 1.166 \\
\hline Napoli: Istituto "Suor Orsola Benincasa" & Private & South & 0.699 & 1.038 & 0.673 \\
\hline Roma: Libera Università LUISS & Private & Centre & 1.719 & 1.582 & 1.086 \\
\hline Roma: Libera Università LUMSA & Private & Centre & 0.686 & 0.925 & 0.742 \\
\hline Roma: UNINT & Private & Centre & 0.561 & 0.937 & 0.599 \\
\hline Roma: Università "Campus Bio-Medico" & Private & Centre & 1.412 & 1.000 & 1.412 \\
\hline Università "KORE" & Private & South & 0.497 & 0.799 & 0.623 \\
\hline Ancona: Università Politecnica delle Marche & Public & Centre & 1.105 & 1.092 & 1.012 \\
\hline Arcavacata di Rende: Università della Calabria & Public & South & 0.941 & 1.142 & 0.824 \\
\hline Bari: Politecnico & Public & South & 1.145 & 0.864 & 1.325 \\
\hline Bari: Università degli studi & Public & South & 0.928 & 1.099 & 0.844 \\
\hline Benevento: Università degli studi del Sannio & Public & South & 1.033 & 0.769 & 1.344 \\
\hline Bergamo: Università degli studi & Public & North & 1.205 & 1.324 & 0.910 \\
\hline Bologna: Università degli studi & Public & North & 1.223 & 1.355 & 0.903 \\
\hline Brescia: Università degli studi & Public & North & 1.073 & 1.249 & 0.859 \\
\hline Cagliari: Università degli studi & Public & South & 1.236 & 1.322 & 0.935 \\
\hline Camerino: Università degli studi & Public & Centre & 1.377 & 1.419 & 0.970 \\
\hline Campobasso: Università del Molise & Public & South & 1.411 & 1.931 & 0.731 \\
\hline Cassino: Università degli studi & Public & Centre & 1.049 & 1.395 & 0.752 \\
\hline Catania: Università degli studi & Public & South & 0.942 & 0.783 & 1.203 \\
\hline Catanzaro: Università "Magna Grecia" & Public & South & 0.959 & 1.226 & 0.782 \\
\hline Chieti: Università Gabriele D’Annunzio & Public & South & 0.784 & 1.115 & 0.703 \\
\hline Ferrara: Università degli studi & Public & North & 1.149 & 1.177 & 0.976 \\
\hline Firenze: Università degli studi & Public & Centre & 1.172 & 1.049 & 1.118 \\
\hline Foggia: Università degli studi & Public & South & 0.944 & 0.956 & 0.988 \\
\hline Genova: Università degli studi & Public & North & 0.989 & 0.948 & 1.044 \\
\hline L'Aquila: Università degli studi & Public & South & 0.834 & 0.920 & 0.907 \\
\hline Lecce: Università degli studi & Public & South & 1.805 & 1.429 & 1.263 \\
\hline Macerata: Università degli studi & Public & Centre & 1.019 & 1.618 & 0.630 \\
\hline Messina: Università degli studi & Public & South & 1.018 & 1.390 & 0.732 \\
\hline Milano: Politecnico & Public & North & 1.514 & 0.000 & 1.127 \\
\hline Milano: Università degli studi & Public & North & 0.901 & 0.811 & 1.110 \\
\hline
\end{tabular}


Table 12 continued

\begin{tabular}{|c|c|c|c|c|c|}
\hline University & Type & Area & $\begin{array}{l}\text { Malmquist } \\
\text { index }\end{array}$ & $\begin{array}{l}\text { Efficiency } \\
\text { change }\end{array}$ & $\begin{array}{l}\text { Frontier } \\
\text { shift }\end{array}$ \\
\hline Milano-Bicocca: Università degli studi & Public & North & 0.977 & 1.055 & 0.926 \\
\hline Modena e Reggio Emilia: Università degli studi & Public & North & 1.152 & 1.163 & 0.991 \\
\hline Napoli: Seconda Università degli studi & Public & South & 0.984 & 1.019 & 0.965 \\
\hline Napoli: Università degli studi "Federico II" & Public & South & 1.208 & 1.202 & 1.005 \\
\hline Napoli: Università degli studi “L' Orientale" & Public & South & 1.001 & 1.575 & 0.635 \\
\hline Napoli: Università degli studi "Parthenope" & Public & South & 1.122 & 1.383 & 0.811 \\
\hline Padova: Università degli studi & Public & North & 1.118 & 1.305 & 0.857 \\
\hline Palermo: Università degli studi & Public & South & 1.007 & 1.407 & 0.715 \\
\hline Parma: Università degli studi & Public & North & 0.947 & 1.218 & 0.778 \\
\hline Pavia: Università degli studi & Public & North & 1.077 & 1.081 & 0.996 \\
\hline Perugia: Università degli studi & Public & Centre & 1.018 & 0.966 & 1.053 \\
\hline Perugia: Università per stranieri & Public & Centre & 0.783 & 1.222 & 0.641 \\
\hline Pisa: Università degli studi & Public & Centre & 1.257 & 1.189 & 1.057 \\
\hline Potenza: Università della Basilicata & Public & South & 0.936 & 1.072 & 0.873 \\
\hline Reggio Calabria: Università Mediterranea & Public & South & 1.020 & 1.120 & 0.911 \\
\hline Roma: III Università degli studi & Public & Centre & 0.910 & 1.118 & 0.814 \\
\hline Roma: Università degli studi "La Sapienza" & Public & Centre & 1.813 & 1.707 & 1.062 \\
\hline Roma: Università di "Tor Vergata" & Public & Centre & 1.124 & 1.138 & 0.987 \\
\hline Salerno: Università degli studi & Public & South & 1.728 & 1.514 & 1.141 \\
\hline Sassari: Università degli studi & Public & South & 1.261 & 1.527 & 0.826 \\
\hline Siena: Università degli studi & Public & Centre & 0.827 & 1.036 & 0.799 \\
\hline Siena: Università per stranieri & Public & Centre & 1.376 & 1.762 & 0.781 \\
\hline Teramo: Università degli studi & Public & South & 0.916 & 1.288 & 0.711 \\
\hline Torino: Politecnico & Public & North & 1.790 & 1.461 & 1.225 \\
\hline Torino: Università degli studi & Public & North & 0.894 & 0.895 & 0.999 \\
\hline Trento: Università degli studi & Public & North & 1.123 & 0.872 & 1.288 \\
\hline Trieste: Università degli studi & Public & North & 0.993 & 1.111 & 0.894 \\
\hline Udine: Università degli studi & Public & North & 1.173 & 1.290 & 0.909 \\
\hline Urbino: Università degli studi & Public & Centre & 1.025 & 1.460 & 0.702 \\
\hline Varese: Università dell’ Insubria & Public & North & 0.988 & 1.309 & 0.755 \\
\hline Venezia: Università degli studi “Cà Foscari” & Public & North & 1.249 & 1.483 & 0.842 \\
\hline Venezia: Università IUAV & Public & North & 1.056 & 1.362 & 0.776 \\
\hline $\begin{array}{l}\text { Vercelli: Università degli studi } \\
\text { del Piemonte orientale }\end{array}$ & Public & North & 1.076 & 1.056 & 1.019 \\
\hline Verona: Università degli studi & Public & North & 1.410 & 1.494 & 0.944 \\
\hline Viterbo: Università della Tuscia & Public & Centre & 1.164 & 1.001 & 0.000 \\
\hline
\end{tabular}

As can be seen in Table 13 (which provides an overall synthesis), the overall efficiency appears to be increased over the 5 year examined, and this improvement is mainly due to pure efficiency. 
Table 13 Statistics on

Malmquist index by type of

university and geographical area

\begin{tabular}{llll}
\hline Malmquist index & Total & Private & Public \\
\hline Total & & & \\
Mean & 1.091 & 0.962 & 1.121 \\
SD & 0.264 & 0.332 & 0.235
\end{tabular}

North

$\begin{array}{llll}\text { Mean } & 1.115 & 1.036 & 1.140 \\ \text { SD } & 0.194 & 0.122 & 0.206\end{array}$

Centre

$\begin{array}{llll}\text { Mean } & 1.126 & 1.094 & 1.135\end{array}$

$\begin{array}{llll}\text { SD } & 0.312 & 0.485 & 0.246\end{array}$

South

\begin{tabular}{llll} 
Mean & 1.039 & 0.613 & 1.094 \\
SD & 0.283 & 0.085 & 0.251 \\
\hline Efficiency change & Total & Private & Public \\
\hline Total & & & \\
Mean & 1.172 & 1.033 & 1.204 \\
SD & 0.323 & 0.404 & 0.291 \\
North & & & \\
Mean & 1.114 & 1.041 & 1.137 \\
SD & 0.376 & 0.520 & 0.314
\end{tabular}

Centre

$\begin{array}{llll}\text { Mean } & 1.243 & 1.111 & 1.278 \\ \text { SD } & 0.268 & 0.273 & 0.255\end{array}$

South

\begin{tabular}{llll} 
Mean & 1.184 & 0.909 & 1.220 \\
SD & 0.280 & 0.099 & 0.276 \\
\hline Frontier shift & Total & Private & Public \\
\hline Total & & & \\
Mean & 0.901 & 0.854 & 0.911 \\
SD & 0.215 & 0.233 & 0.209 \\
North & & & \\
Mean & 0.939 & 0.872 & 0.960 \\
SD & 0.150 & 0.175 & 0.135 \\
Centre & & & \\
Mean & 0.854 & 0.960 & 0.825 \\
SD & 0.287 & 0.315 & 0.271 \\
South & & & \\
Mean & 0.892 & 0.673 & 0.921 \\
SD & 0.207 & 0.041 & 0.203 \\
\hline
\end{tabular}


Table 14 Malmquist indexes' confidence intervals, period 2007-2011

\begin{tabular}{|c|c|c|c|c|c|}
\hline & \multicolumn{2}{|c|}{$\begin{array}{l}\text { DMU with Malmquist index } \\
\text { statistically significant }\end{array}$} & \multirow[t]{2}{*}{$\begin{array}{l}\text { Mean of Malmquist } \\
\text { index* }\end{array}$} & \multicolumn{2}{|c|}{$\begin{array}{l}\text { Malmquist } \\
\text { index }>1^{*}\end{array}$} \\
\hline & $\%$ & $\mathrm{~N}$ & & $\%$ & $\mathrm{~N}$ \\
\hline Private & 78.6 & 11 & 0.972 & 45.5 & 5 \\
\hline Public & 76.7 & 46 & 1.157 & 73.9 & 34 \\
\hline Total & 77.0 & 57 & 1.121 & 68.4 & 39 \\
\hline
\end{tabular}

* Considering only DMU with Malmquist index statistically significant

The universities that have seen a higher improvement are those located in central Italy, while the analysis by type of university shows a greater improvement for public universities. This evidence is apparently in contrast with what has been shown previously, since the average values tend to mask the great heterogeneity of the system. It seems to emerge a "catching up" effect of the public universities (respect to private universities) and of Southern and central universities (respect the Northern ones), even if these changes happen at a slow rate.

The results also highlight a great heterogeneity in the country: the efficiency is widespread and is not characteristic of a single type of university.

We finally compared our results with the statistically significant ones, calculated at significance level of $5 \%$ (see Table 14). The cases in which the indices are significantly different from unity are over $76 \%$ and their average value is very similar to the original ones. The number of cases in which we can observe a statistically significant improvement in productivity are $45.5 \%$ for private universities and $73.9 \%$ for public ones, confirming the greater improvement for public universities already registered.

\subsection{Exploring Universities' Efficiency Through a Second-Stage Regression}

Through the second level regression we can try to understand which are the major determinants of efficiency. The second-level regression has been implemented through a Tobit regression; efficiency scores are the dependent variable. The explanatory variables in the model are the following:

- the total number of students in the university (total students/1000);

- a dummy variable to differentiate the type of university (public, private) (type of university);

- a dummy variable to differentiate the universities of central Italy (Geographical Area: Centre);

- a dummy variable to differentiate the universities located in the South of Italy (Geographical Area: South);

- a dummy variable to differentiate universities that offer courses in medicine (medicine courses);

- the share of revenue from student fees (except for year 2011, for which these data are not publicly available) (revenues from fees). 
The results are reported in Table 15. The geographical area appears to be the major determinant of efficiency, being always statistically correlated with the efficiency scores. The dummy variable "Southern Italy" shows a negative coefficient, which means that the university of the South are related to lower efficiency scores. The type of university (public/private) appears instead significant only in some years, but with a negative relationship between the efficiency scores and the typology "public university". We can also observe that the differential in efficiency between public and private institutions has increased over the years examined. The variables "geographical area: centre", presence of medicine courses and "revenues from fees" are not significant in any year.

The implementation of the tobit regression adding two new variables: the share of foreign students and the proportion of BA students over MA, gives the results reported in Table 16. In this case the type of university is always significant, with a positive relation between private institutions and higher level of efficiency. The dummy variable "Southern Italy" remains significant in every year, with the same relation founded before. The share of foreign students appears to be significant in 4 years. The proportion of BA students over MA students is significant only in few years.

Implementing the tobit model only with the universities located in Northern Italy, we observe that all variables except the share of foreign students are significant. ${ }^{16}$ The total number of students, the proportion of BA over MA students and the presence of medicine courses have a limited coefficient, while the type of university (to be a private university) appear to be the major determinant of efficiency while limiting the analysis on the North of Italy (Table 17).

\section{Discussion, Policy Implications and Conclusions}

This work has analysed public and private Italian universities.

After a short comparison between the two systems, we have carried out an empirical analysis to investigate the technical efficiency of Italian universities in the years 20072011, using public data from the Statistical Office of the Ministry of Education and by ANVUR. The aim of the study was to verify the existence of a difference from the point of view of efficiency between public and private university system, and if this efficiency is decreased or increased over the years.

The implementation of the DEA model with inputs the total number of students and faculty, and with outputs the total number of graduates and revenues resulting from scientific research has revealed differences related to the type of universities (private universities appear to be relatively more efficient than public ones) and geographical area (Northern universities appear to be relatively more efficient than those of the centre and the South). The model is robust to various alternative specifications; variables related to teaching seem to affect more efficiency, and in particular data related to Bachelor programs.

\footnotetext{
16 It is not possible to include the share of revenue from student fees because they are not publicly available for year 2011.
} 
Table 15 The determinants of efficiency: second stage Tobit analysis, by year

\begin{tabular}{|c|c|c|c|c|c|}
\hline 2007 & Coeff. & Std. Error & $\mathrm{t}$ & $P>|t|$ & Sig. \\
\hline Total students/1000 & 0.003 & 0.001 & 4.23 & 0.000 & *** \\
\hline Type of university & 0.090 & 0.053 & 1.69 & 0.095 & \\
\hline Geogr Area: Centre & -0.034 & 0.039 & -0.89 & 0.379 & \\
\hline Geogr Area: South & -0.119 & 0.035 & -3.40 & 0.001 & $* *$ \\
\hline Medicine courses & 0.004 & 0.036 & 0.11 & 0.912 & \\
\hline Revenues from fees & 0.117 & 0.151 & 0.78 & 0.440 & \\
\hline Constant & 0.511 & 0.070 & 7.32 & 0.000 & $* * *$ \\
\hline 2008 & Coeff. & Std. error & $\mathrm{t}$ & $P>|t|$ & Sig. \\
\hline Total students/1000 & 0.003 & 0.001 & 4.32 & 0.000 & $* * *$ \\
\hline Type of university & 0.114 & 0.057 & 2.01 & 0.048 & $*$ \\
\hline Geogr Area: Centre & -0.010 & 0.038 & -0.27 & 0.786 & \\
\hline Geogr Area: South & -0.113 & 0.034 & -3.32 & 0.001 & $* *$ \\
\hline Medicine courses & 0.018 & 0.035 & 0.52 & 0.607 & \\
\hline Revenues from fees & 0.194 & 0.158 & 1.23 & 0.222 & \\
\hline Constant & 0.424 & 0.070 & 6.05 & 0.000 & $* * *$ \\
\hline 2009 & Coeff. & Std. error & $\mathrm{t}$ & $P>|t|$ & Sig. \\
\hline Total students/1000 & 0.003 & 0.001 & 4.93 & 0.000 & $* * *$ \\
\hline Type of university & 0.104 & 0.056 & -1.88 & 0.065 & \\
\hline Geogr Area: Centre & 0.006 & 0.036 & 0.16 & 0.874 & \\
\hline Geogr Area: South & -0.109 & 0.033 & -3.32 & 0.001 & $* *$ \\
\hline Medicine courses & -0.026 & 0.034 & -0.77 & 0.445 & \\
\hline Revenues from fees & 0.205 & 0.137 & 1.49 & 0.140 & \\
\hline Constant & 0.453 & 0.068 & 6.64 & 0.000 & $* * *$ \\
\hline 2010 & Coeff. & Std. error & $\mathrm{t}$ & $P>|t|$ & Sig. \\
\hline Total students/1000 & 0.004 & 0.001 & 5.94 & 0.000 & $* * *$ \\
\hline Type of university & 0.146 & 0.049 & 2.99 & 0.004 & $* * *$ \\
\hline Geogr Area: Centre & -0.043 & 0.032 & -1.32 & 0.192 & \\
\hline Geogr Area: South & -0.131 & 0.030 & -4.42 & 0.000 & $* * *$ \\
\hline Medicine courses & 0.024 & 0.030 & 0.78 & 0.439 & \\
\hline Revenues from fees & 0.213 & 0.128 & 1.66 & 0.103 & \\
\hline Constant & 0.373 & 0.063 & 5.96 & 0.000 & *** \\
\hline 2011 & Coeff. & Std. error & $\mathrm{t}$ & $P>|t|$ & Sig \\
\hline Total students/1000 & 0.004 & 0.001 & 5.19 & 0.000 & $* * *$ \\
\hline Type of university & 0.183 & 0.037 & 4.91 & 0.000 & $* * *$ \\
\hline Geogr Area: Centre & -0.032 & 0.035 & -0.90 & 0.370 & \\
\hline Geogr Area: South & -0.103 & 0.032 & -3.19 & 0.002 & $* * *$ \\
\hline Medicine courses & -0.010 & 0.033 & -0.30 & 0.766 & \\
\hline Constant & 0.387 & 0.064 & 6.01 & 0.000 & $* * *$ \\
\hline
\end{tabular}


Table 16 The determinants of efficiency: second stage Tobit analysis (second regression), by year

\begin{tabular}{|c|c|c|c|c|c|}
\hline 2007 & Coeff. & Std. error & $\mathrm{t}$ & $P>|t|$ & Sig. \\
\hline Total students/1000 & 0.003 & 0.001 & 4.51 & 0.000 & $* * *$ \\
\hline Type of university & 0.146 & 0.056 & 2.58 & 0.012 & $*$ \\
\hline Geogr Area: Centre & -0.044 & 0.037 & -1.18 & 0.242 & \\
\hline Geogr Area: South & -0.085 & 0.039 & -2.21 & 0.031 & $*$ \\
\hline Medicine courses & -0.013 & 0.037 & 0.34 & 0.732 & \\
\hline Revenues from fees & -0.000 & 0.160 & 0.00 & 0.440 & \\
\hline Foreign students & 1.815 & 1.105 & 1.64 & 0.105 & \\
\hline BA/MA students & -0.009 & 0.005 & -1.84 & 1.000 & \\
\hline Constant & 0.467 & 0.077 & 6.07 & 0.000 & $* * *$ \\
\hline 2008 & Coeff. & Std. error & $\mathrm{t}$ & $P>|t|$ & Sig. \\
\hline Total students/1000 & 0.003 & 0.001 & 4.89 & 0.000 & $* * *$ \\
\hline Type of university & 0.180 & 0.060 & 3.02 & 0.004 & $* *$ \\
\hline Geogr Area: Centre & -0.018 & 0.035 & -0.50 & 0.618 & \\
\hline Geogr Area: South & -0.070 & 0.035 & -1.99 & 0.050 & $*$ \\
\hline Medicine courses & 0.005 & 0.035 & 0.15 & 0.885 & \\
\hline Revenues from fees & 0.062 & 0.173 & 0.36 & 0.722 & \\
\hline Foreign students & 2.350 & 0.790 & 2.97 & 0.004 & $* *$ \\
\hline BA/MA students & -0.013 & 0.007 & -1.82 & 0.073 & \\
\hline Constant & 0.351 & 0.071 & 4.93 & 0.000 & $* * *$ \\
\hline 2009 & Coeff. & Std. error & $\mathrm{t}$ & $P>|t|$ & Sig. \\
\hline Total students/1000 & 0.004 & 0.001 & 5.35 & 0.000 & $* * *$ \\
\hline Type of university & 0.185 & 0.061 & 3.02 & 0.004 & $* *$ \\
\hline Geogr Area: Centre & 0.001 & 0.034 & 0.02 & 0.986 & \\
\hline Geogr Area: South & -0.077 & 0.036 & -2.12 & 0.038 & $*$ \\
\hline Medicine courses & -0.047 & 0.035 & -1.36 & 0.179 & \\
\hline Revenues from fees & 0.013 & 0.160 & 0.08 & 0.936 & \\
\hline Foreign students & 1.756 & 0.840 & 2.09 & 0.040 & $*$ \\
\hline BA/MA students & -0.020 & 0.009 & -2.08 & 0.042 & $*$ \\
\hline Constant & 0.403 & 0.074 & 5.41 & 0.000 & $* * *$ \\
\hline 2010 & Coeff. & Std. error & $\mathrm{t}$ & $P>|t|$ & Sig. \\
\hline Total students/1000 & 0.004 & 0.001 & 6.51 & 0.000 & $* * *$ \\
\hline Type of university & 0.219 & 0.059 & 3.71 & 0.000 & $* * *$ \\
\hline Geogr Area: Centre & -0.052 & 0.031 & -1.65 & 0.103 & \\
\hline Geogr Area: South & -0.092 & 0.034 & -2.75 & 0.008 & $* *$ \\
\hline Medicine courses & 0.018 & 0.032 & 0.58 & 0.563 & \\
\hline Revenues from fees & 0.066 & 0.161 & 0.41 & 0.685 & \\
\hline Foreign students & 1.953 & 0.733 & 2.66 & 0.010 & $* *$ \\
\hline
\end{tabular}


Table 16 continued

\begin{tabular}{|c|c|c|c|c|c|}
\hline 2010 & Coeff. & Std. error & $\mathrm{t}$ & $P>|t|$ & Sig. \\
\hline BA/MA students & -0.016 & 0.010 & -1.57 & 0.121 & \\
\hline Constant & 0.292 & 0.069 & 4.24 & 0.000 & $* * *$ \\
\hline 2011 & Coeff. & Std. error & $\mathrm{t}$ & $P>|t|$ & Sig. \\
\hline Total students/1000 & 0.367 & 0.674 & 5.54 & 0.000 & $* * *$ \\
\hline Type of university & 0.193 & 0.036 & 5.40 & 0.000 & $* * *$ \\
\hline Geogr Area: Centre & -0.030 & 0.034 & -0.89 & 0.376 & \\
\hline Geogr Area: South & -0.074 & 0.035 & -2.10 & 0.040 & $*$ \\
\hline Medicine courses & -0.021 & 0.032 & -0.64 & 0.523 & \\
\hline Foreign students & 1.444 & 0.608 & 2.38 & 0.021 & $*$ \\
\hline BA/MA students & -0.022 & 0.010 & 2.24 & 0.029 & $*$ \\
\hline Constant & 0.392 & 0.071 & 5.52 & 0.000 & $* * *$ \\
\hline
\end{tabular}

Table 17 The determinants of efficiency: second stage Tobit analysis, only Northern universities

\begin{tabular}{llllll}
\hline & Coeff. & Std. error & $\mathrm{t}$ & $\mathrm{P}>|\mathrm{t}|$ & Sig. \\
\hline Total students/1000 & 0.004 & 0.000 & 10.47 & 0.000 & $* * *$ \\
Type of university & 0.180 & 0.021 & 8.71 & 0.000 & $* * *$ \\
Medicine courses & -0.080 & 0.018 & -4.36 & 0.000 & $* * *$ \\
Foreign students & -0.285 & 0.566 & -0.50 & 0.615 & $* * *$ \\
BA/MA students & -0.021 & 0.003 & -7.73 & 0.000 & $* * *$ \\
Constant & 0.486 & 0.038 & 12.88 & 0.000 & \\
\hline
\end{tabular}

Subsequently, we have calculated the Malmquist index, in order to conduct a comparison over years. This analysis has showed that the overall efficiency of Italian universities has increased over the 5 year examined, particularly thanks to an improvement in pure efficiency. The universities that have seen a higher improvement were those located in central Italy and public universities.

To investigate the main determinants of efficiency, we have finally carried out a second level regression, which shows that the geographical area is the major determinant of efficiency: universities located in the South of Italy are related to lower efficiency scores.

This study thus shows how Italian private universities are more efficient than public ones, confirming the impression that the former are able to "produce" more educational and research outputs with the same (or lower) level of inputs. Data also show that differences between Northern and Southern universities persist: it is not possible to attribute to the structural characteristics of universities the differentials in efficiency, as the type of institutions doesn't determine the differential. Differences in efficiency scores do not reside in the structural characteristics of universities but on the management and processes of single institutions. 
Comparing our results to those of other authors, we can compare evidence with studies focused only on the Italian system: Agasisti and Dal Bianco (2006), Monaco (2012), Agasisti and Lezzi (2013). First of all, the gap in efficiency scores between universities in different geographical areas is a common characteristic of these studies. On the other hand, in contradiction to our findings, Agasisti and Lezzi (2013) conclude that productivity growth was due to major technological change-while we find more pure efficiency gains; however they analyse overall change between 2001 and 2011, not including private institutions. They also found a significant relation between the level of student fees and efficiency, while in our analysis this variable is not significant. As emerged in Monaco (2012), also our study denoted that private universities are more efficient than public, although in her paper, having a single academic year, wasn't conducted the Malmquist analysis, so our work innovates in giving a clearer idea about the dynamics of efficiency across sectors. As already cited in the paper, the comparison of some scores reveals that the most efficient institutions of our study also obtain efficiency scores also in Monaco's work.

Our work has three main policy implications. The first evidence is the persistence of a differential in terms of efficiency between Northern and Southern universities, as it has been showed in previous studies. Given the observed trend of performance and efficiency, it is not possible to fill the gap between South and North unless the design of policies specifically targeted. This is a "local" problem, so it is evident that a unique national policy is inefficient in this case. For Northern universities policies aimed to reduce costs are ineffective, because those universities have already reached a good level of efficiency and so there are few margins of improving in this sense. To increase the overall efficiency of the system, and fill the gap between North and South, the national legislature can introduce some actions to permit to Southern universities to study and follow the managerial practices of the most efficient Northern universities. Also, policies should be differentiated for the different areas of the country. The second main result of the study is that private universities are more efficient than public ones. We can therefore say that public universities can somehow "learn" from the private sector. The traditional distinction and separation between Italian public and private universities has no basis in terms of efficiency. The creation of a unique system, in which universities compare themselves and compete, can create more opportunities to improve their practices. In this sense, the separation of funds for financing public universities and private ones, with government funds per student lower for the latter, has no explication for policy purposes. The financing system may be reconsidered with a view on how funds are effectively used, rather than with the actual system primarily based on historical principles. One way to fasten the two systems is to merge the ordinary financing fund for universities (FFO) and the fund deriving from the Law 243 of 1991 to create a unique national financial fund. The third evidence is related to the second stage analysis. If we look at the results we can note that several variables affect the efficiency: revenues from fees, foreign students, etc., but in a non-stable way. This may be due to the fact that data collected from the official sites and used for the present analysis are inadequate for the study of this phenomenon. It could be useful for the central bodies to promote a collection of information related to the managerial practices of universities. The absence of a comparable database on the different managerial aspects of the Italian institutions does not permit to deepen the present 
analysis to understand which are the managerial practices that are associated with higher efficiency scores; exploring some detailed characteristics about the decisionmaking processes and activities can be an interesting direction for taking the efficiency analysis a further step.

Thinking on future research, it should finally be noted that, due to a discontinuity of the time series, in the present work it has not been possible to include data on contract teachers, which for private universities represent a significant share of the total faculty. We can also note that the availability of standardized tests on student achievement, an output indicator already used in some studies for other countries, would help in conducting analysis on the efficiency of universities. The possibility of use individual data on students may also allow a more detailed analysis. Many studies have in fact shown that the results of the education process depend also on the characteristics of the students themselves. We hope that the development of the "Anagrafe degli Studenti" (Census of Students), recently promoted by the Ministry of Education, would help researchers in the next future.

Acknowledgments Part of this work has been realized during the project work for the Master of University Management (Master SUM) at the MIP Politecnico di Milano Graduate School of Business. We are grateful to two anonymous referees for their useful and challenging comments and suggestions. All eventual errors are our solely responsibility.

\section{References}

Agasisti T, Dal Bianco A (2006) Data envelopment analysis of the Italian University System: theoretical issues and policy implications. Int J Bus Perform Manag 8(4):344-367

Agasisti T, Johnes G (2009) Beyond frontiers: comparing the efficiency of higher education decision-making units across more than one country. Educ Econ 17(1):59-79

Agasisti T, Lezzi M (2013) The efficiency of Italian public universities in the medium run (2001-2011): a data envelopment analysis. Politecnico di Milano School of Management, Working Paper, Mimeo

Agasisti T, Pérez-Esparrels C (2010) Comparing efficiency in a cross-country perspective: the case of Italian and Spanish state universities. Hig Educ 59(1):85-193

Agasisti T, Pohl C (2012) Comparing German and Italian public universities: convergence or divergence in the higher education landscape. Manag Decis Econ 33(1):71-85

Bergantino AS, Capozza C, Porcelli F (2012) Measuring the efficiency of the Italian University system: the role of market structure. A two step DEA analysis at faculty level. XXV Conferenza della Società italiana di economia pubblica

Clark BR (1983) The higher education system: academic organization in cross-national perspective. University of California Press, Berkeley

Cohn E, Rhine SLW, Santos MC (1989) Institutions of higher education as multi-product firms: economies of scale and scope. Rev Econ Stat 71(2):284-290

Cooper WW, Seiford LM, Tone K (2006) Introduction to data envelopment analysis and its uses. Springer, New York

Daraio C, Simar L (2007) Advanced robust and nonparametric methods in efficiency analysis. Methodology and applications. Springer, New York

Johnes G (1993) The economics of education. The MacMillan Press, London

Johnes J (2004) Efficiency measurement. In: Johnes G, Johnes J (eds) International handbook on the economics of education. Edward Elgar Publishing Ltd, Cheltenham

Johnes J (2006a) Measuring teaching efficiency in higher education: an application of data envelopment analysis to economics graduates from UK universities. Eur J Open Res 174(1):443-456

Johnes J (2006b) Data envelopment analysis and its application to the measurement of efficiency in higher education. Econ Educ Rev 25(3):273-288 
Johnes J, Taylor J (1990) Performance indicators in higher education: UK Universities. Open University Press and the Society for Research into Higher Education, Milton Keynes

Levy DC (2012) How important is private higher education in Europe? A regional analysis in global context. Eur J Educ 47(2):178-197

Monaco L (2012) Measuring Italian University efficiency: a non-parametric approach. MPRA Paper No 37949

Parteka A, Wolszczak-Derlacz J (2013) Dynamics of productivity in higher education-cross European evidence based on bootstrapped Malmquist indices. J Prod Anal 40(1):67-82

Pesenti R, Ukovich W (1999) Evaluating academic activities using DEA. Internal Report, DEEI-Università di Trieste

Rizzi D (1999) L'efficienza dei dipartimenti dell'Università Ca' Foscari di Venezia via DEA e DFA, Economia pubblica

Simar L, Wilson P (1999) Estimating and bootstrapping Malmquist indices. Eur J Oper Res 115:459-471

Simar L, Wilson P (2000) A general methodology for bootstrapping in non-parametric frontier models. J Appl Stat 27(6):779-802

Turri M (2011) L'università in transizione. Governance, struttura economica e valutazione, Guerini studio, Milano

Wilson PW (2008) FEAR 1.0: a software package for frontier efficiency analysis with R. Socio-Econ Plan Sci 42:247-254

Worthington A (2001) An empirical survey of frontier efficiency measurement techniques in education. Educ Econ 9(3):245-268

Zhu J (2003) Quantitative models for performance evaluation and benchmarking. Kluwer, Boston 